Nevada

Environmental

Restoration

Project

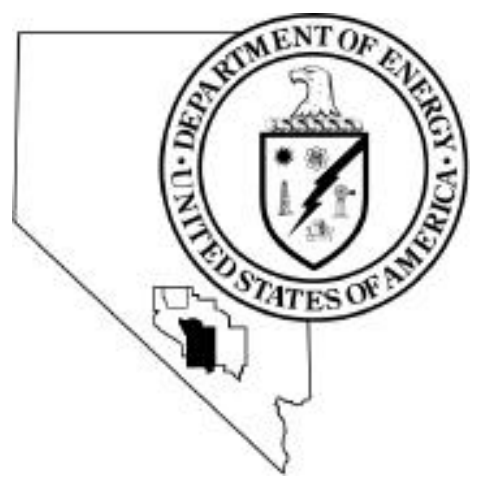

Corrective Action Decision Document for Corrective Action Unit 230:

Area 22 Sewage Lagoons and

Corrective Action Unit 320:

Area 22 Desert Rock Airport Strainer Box, Nevada Test Site, Nevada

Controlled Copy No.:

Revision No.: 0

April 2000

Approved for public release; further dissemination unlimited.

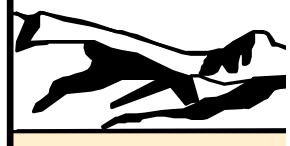

Environmental Restoration

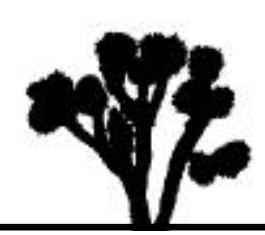

Division 
Available for public sale, in paper, from:
U.S. Department of Commerce
National Technical Information Service
5285 Port Royal Road
Springfield, VA 22161
Phone: 800.553 .6847
Fax: 703.605.6900
Email: orders@ntis.fedworld.gov
Online ordering: http//www.ntis.gov/ordering.htm

Available electronically at: http://www.doe.gov/bridge.

Available for a processing fee to U.S. Department of Energy and its contractors, in paper, from:
U.S. Department of Energy
Office of Scientific and Technical Information
P.O. Box 62
Oak Ridge, TN 37831-0062
Phone: 865.576 .8401
Fax: 865.576.5728
Email: reports@adonis.osti.gov

Reference herein to any specific commercial product, process, or service by trade name, trademark, manufacturer, or otherwise, does not necessarily constitute or imply its endorsement, recommendation, or favoring by the United States Government or any agency thereof or its contractors or subcontractors. 


\section{CORRECTIVE ACTION DECISION DOCUMENT FOR CORRECTIVE ACTION UNIT 230: AREA 22 SEWAGE LAGOONS AND CORRECTIVE ACTION UNIT 320: AREA 22 DESERT ROCK AIRPORT STRAINER BOX, NEVADA TEST SITE, NEVADA}

DOE Nevada Operations Office

Las Vegas, Nevada

Controlled Copy No.:

Revision No.: 0

April 2000

Approved for public release; further dissemination unlimited. 


\section{CORRECTIVE ACTION DECISION DOCUMENT FOR CORRECTIVE ACTION UNIT 230: \\ AREA 22 SEWAGE LAGOONS AND \\ CORRECTIVE ACTION UNIT 320:}

AREA 22 DESERT ROCK AIRPORT STRAINER BOX, NEVADA TEST SITE, NEVADA

Approved by:

Janet Appenzeller-Wing, Project Manager

Industrial Sites Project

Approved by: Signature Approved

Date: $4 / 20 / 2000$

Runore C. Wycoff, Division Director

Environmental Restoration Division 


\section{Table of Contents}

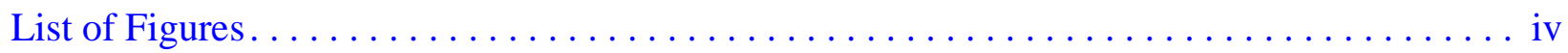

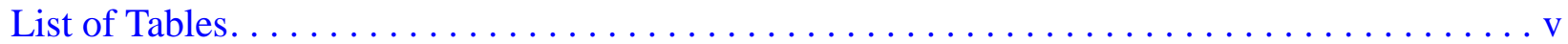

List of Acronyms and Abbreviations $\ldots \ldots \ldots \ldots \ldots \ldots \ldots \ldots \ldots \ldots \ldots \ldots \ldots \ldots \ldots \ldots$

Executive Summary . . . . . . . . . . . . . . . . . . . . . . . ES-1

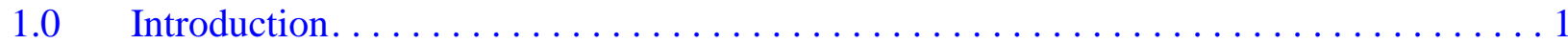

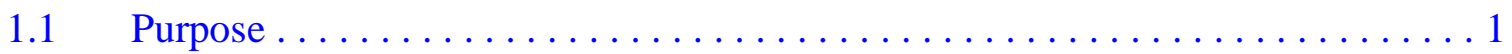

$1.2 \quad$ Scope. . . . . . . . . . . . .

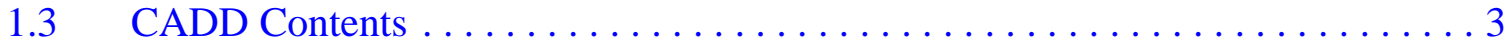

2.0 Corrective Action Investigation Summary $\ldots \ldots \ldots \ldots \ldots \ldots \ldots \ldots \ldots \ldots$

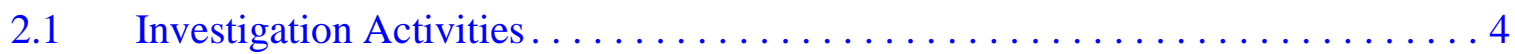

$2.2 \quad$ Results................................... 5

$2.3 \quad$ Need for Corrective Action. . . . . . . . . . . . . . . . . . . . 6

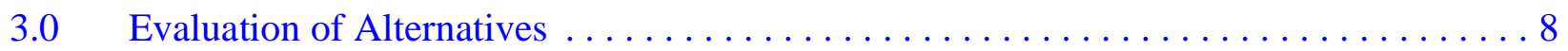

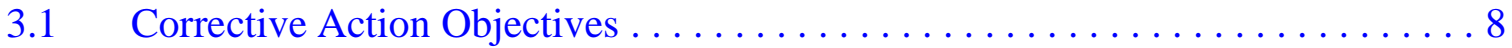

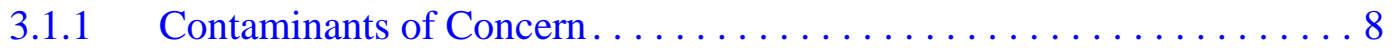

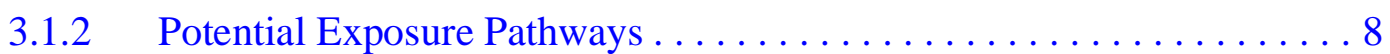

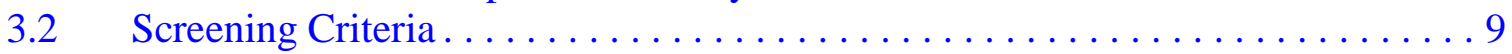

3.2.1 Corrective Action Standards. . . . . . . . . . . . . . . . . . . . . 9

3.2.2 Remedy Selection Decision Factors. . . . . . . . . . . . . . . . 11

3.3 Development of Corrective Action Alternatives . . . . . . . . . . . . . 12

3.3.1 Alternative 1 - No Further Action . . . . . . . . . . . . . 15

3.3.2 Alternative 2 - Closure in Place with Administrative Controls . . . . . . 15

3.3.3 Alternative 3 - Excavation and Removal ................. 16

3.4 Evaluation and Comparison of Alternatives. . . . . . . . . . . . 16

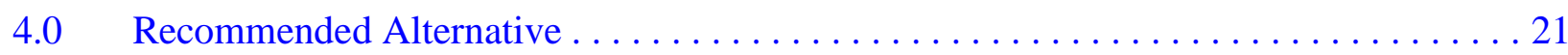

$5.0 \quad$ References..................................... 22

Appendix A - Corrective Action Investigation Report for CAU 230: Area 22 Sewage Lagoons and CAU 320: Area 22 Desert Rock Airport Strainer Box, Nevada Test Site, Nevada

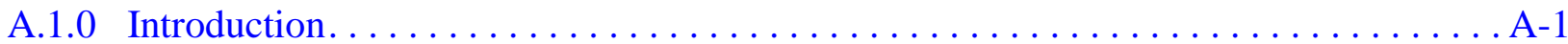

A.1.1 Project Objectives . . . . . . . . . . . . . . .

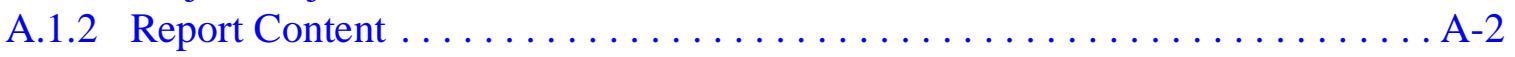

A.2.0 Field Investigation and Sampling Activities. . . . . . . . . . . . . . .

A.2.1 Site Descriptions and Conditions $\ldots \ldots \ldots \ldots \ldots \ldots \ldots \ldots \ldots \ldots \ldots \ldots \ldots \ldots \ldots \ldots$ 


\section{Table of Contents (Continued)}

A.2.1.1 Sample Locations . . ........................ A-4

A.2.1.2 Geoprobe ${ }^{\circledR}$ Soil Sampling ....................... A-5

A.2.1.3 Trench/Test Pit Soil Sampling ...................... A-5

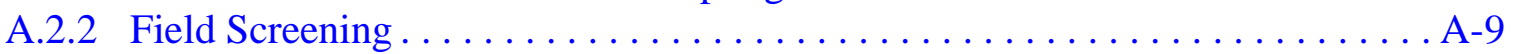

A.2.3 Sludge Bed Description and Cross-Section $\ldots \ldots \ldots \ldots \ldots \ldots \ldots \ldots \ldots$ A- 10

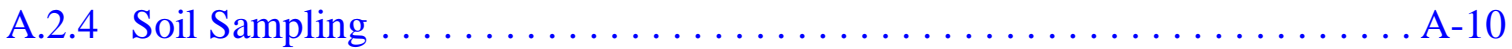

A.2.5 Number of Samples Collected and Submitted for Analyses. . . . . . . . . . . A-12

A.2.6 Geology ................................... A-12

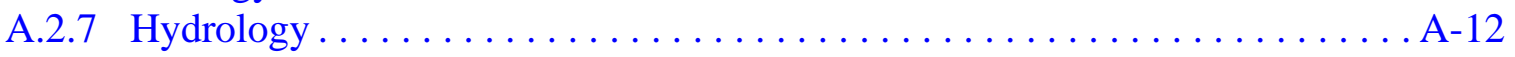

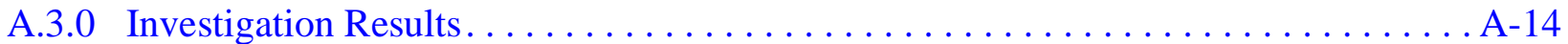

A.3.1 Total Volatile Organic Compound Analytical Results................ A-15

A.3.2 Total Semivolatile Organic Compound Analytical Results . . . . . . . . . . A-16

A.3.3 Total Petroleum Hydrocarbon Results . . . . . . . . . . . . . . . . . A-16

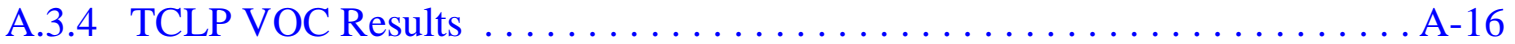

A.3.5 TCLP SVOC Results . ............................ A-16

A.3.6 TCLP RCRA Metals Results . . . . . . . . . . . . . . . . . . . . . . . . A-17

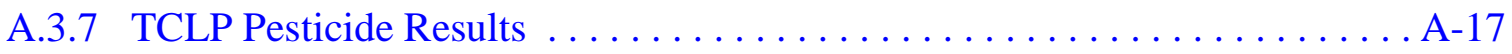

A.3.8 Gamma Spectrometry Results $\ldots \ldots \ldots \ldots \ldots \ldots \ldots \ldots \ldots \ldots \ldots$ A -17

A.4.0 Quality Assurance . . . . . . . . . . . . . . . . . . . . . . . . . . . . A-18

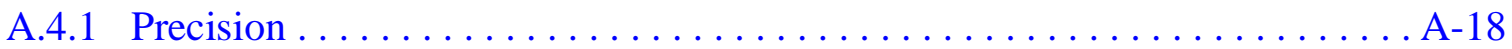

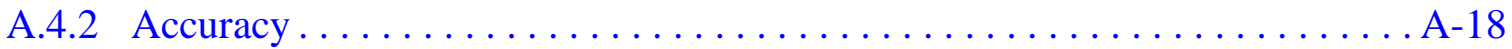

A.4.3 Representativeness . . . . . . . . . . . . . . . . . . . . . . . . . A-19

A.4.4 Completeness ................................... A-19

A.4.5 Comparability ............................... A 19

A.4.6 Tier I and Tier II Data Evaluations. . . . . . . . . . . . . . . . . A-20

A.4.6.1 Tier I Evaluation. . . . . . . . . . . . . . . . . . . . A-20

A.4.6.2 Tier II Evaluation . . . . . . . . . . . . . . . . . . . . . A-21

A.4.6.3 Tier III ................................. A-23

A.4.7 Quality Control Samples............................ A-23

A.4.7.1 Field Quality Control Samples.................... A-24

A.4.7.2 Laboratory Quality Control Samples ................. A-25

A.4.8 Field Nonconformances . . . . . . . . . . . . . . . . . . . . . . A-27

A.4.9 Laboratory Nonconformances $\ldots \ldots \ldots \ldots \ldots \ldots \ldots \ldots \ldots \ldots \ldots \ldots$ A 27

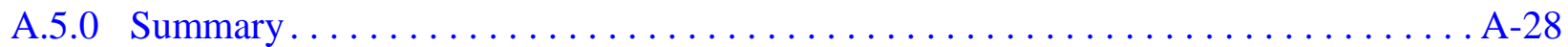

A.6.0 References Cited . . . . . . . . . . . . . . . . . . . . . . . . . . A-29

Appendix B - Cost Estimates 


\section{Table of Contents (Continued)}

\section{Appendix C - Evaluation of Risk}

C.1.0 Evaluation of Risk $\ldots \ldots \ldots \ldots \ldots \ldots \ldots \ldots \ldots \ldots \ldots \ldots \ldots \ldots \ldots \ldots \ldots$

Appendix D - Manhole Investigation/CADD Photos

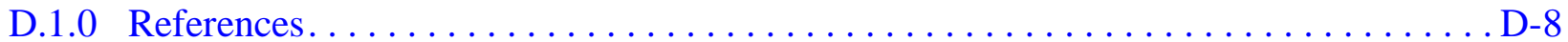

Appendix E - Response to NDEP Comments 


\section{List of Figures}

Number

1-1 CAU 230/320 Sewage Lagoons Site Location Map, Nevada Test Site . . . . . . . . . 2

A.2-1 Soil Sample Locations Shown on a 1990 Aerial Photograph for the

CAU 230/320 Sewage Lagoons Site, Area 22, Nevada Test Site, Nevada . . . . . . . . A-6

A.2-2 Generalized Cross-Section of the Sludge Bed, CAU 230/320 Sewage

Lagoons Site, Area 22, Nevada Test Site, Nevada . . . . . . . . . . . . . . . A-11

D-1 CAU 230/320 Manhole Locations Area 22, Nevada Test Site . . . . . . . . . . . . . . D-2 


\section{List of Tables}

Number

3-1 Detailed Evaluation of Alternatives. . . . . . . . . . . . . . . . . . . 17

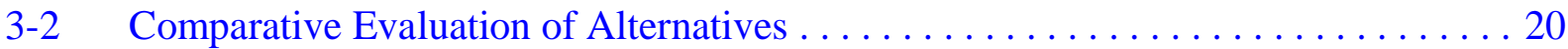

A.2-1 Samples Collected and Submitted for Laboratory Analyses for the CAU 230/320 Area 22 Sewage Lagoons Corrective Action Investigation . . . . . . A-7

A.3-1 Laboratory Analytical Methods Conducted for Samples Collected During the CAU 230/320 Area 22 Sewage Lagoons Corrective Action Investigation . . . A-14

A.3-2 Soil Sample Results for Total Volatile Organic Compounds Detected Above Minimum Reporting Limits, CAU 230/320 Area 22 Sewage Lagoons Site, Nevada Test Site.

A.3-3 Soil Sample Results for Total Petroleum Hydrocarbons Detected Above Minimum Reporting Limits, CAU 230/320 Area 22 Sewage Lagoons Site, Nevada Test Site

A.3-4 Summary of Gamma Spectrometry Results Detected Above Minimum Reporting Limits, CAU 230/320 Area 22 Sewage Lagoons, Nevada Test Site . . . . . . . . . . . . . . . . . . . . . . . . . . . . . . . A-17

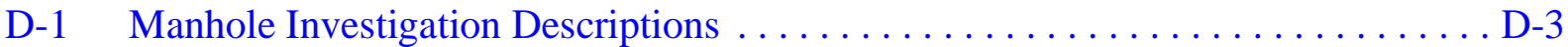




\section{List of Acronyms and Abbreviations}

bgs Below ground surface

CADD Corrective Action Decision Document

CAIP Corrective Action Investigation Plan

CAS Corrective Action Site

CAU Corrective Action Unit

CFR Code of Federal Regulations

CLP Contract Laboratory Program

COC Contaminant(s) of concern

COPC Contaminant(s) of potential concern

CRDL Contract-required detection limit(s)

DOE/NV U.S. Department of Energy, Nevada Operations Office

DQO Data Quality Objective(s)

EPA U.S. Environmental Protection Agency

FFACO Federal Facility Agreement and Consent Order

FSL Field-screening levels

$\mathrm{ft} \quad$ Foot (feet)

ICP Inductively coupled plasma

in. $\quad \operatorname{Inch}(\mathrm{es})$

LCS Laboratory control sample(s)

$\mathrm{mg} / \mathrm{kg} \quad$ Milligram(s) per kilogram

mi Mile(s)

MS/MSD Matrix spike and matrix spike duplicate

NAC Nevada Administrative Code

NDEP Nevada Division of Environmental Protection

NEDS Nonevident Explosive Destruct System

NIST National Institute of Standards

NRS Nevada Revised Statutes 


\section{List of Acronyms and Abbreviations (Continued)}

NTS Nevada Test Site

PAL Preliminary action level(s)

PB Preparation blank(s)

ppm Part(s) per million

PVC Polyvinyl chloride

QA Quality assurance

QAPP Quality Assurance Project Plan

QC Quality control

RCRA Resource Conservation and Recovery Act

RPD Relative percent difference

SDG Sample delivery group

SVOC Semivolatile organic compound(s)

TCLP Toxicity Characteristic Leaching Procedure

TPH Total petroleum hydrocarbon(s)

VOC Volatile organic compound(s)

$\% \mathrm{R} \quad$ Percent recovery 


\section{Executive Summary}

This Corrective Action Decision Document has been prepared for Corrective Action Unit 230, Area 22 Sewage Lagoons and Corrective Action Unit 320, Area 22 Desert Rock Airport Strainer Box, Nevada Test Site, Nevada, in accordance with the Federal Facility Agreement and Consent Order (1996). These Corrective Action Units will be collectively referred to as Corrective Action Unit 230/320 or as the Area 22 Sewage Lagoons site. The Area 22 Sewage Lagoons site is comprised of two Corrective Action Sites, 22-03-01, Sewage Lagoon and 22-99-01, Strainer Box. The Area 22 Sewage Lagoons site also includes a buried Imhoff Tank, sludge bed, and associated sewer piping.

The purpose of this Corrective Action Decision Document is to identify and provide a rationale for the selection of a recommended corrective action alternative for these Corrective Action Sites.

The scope of this Corrective Action Decision Document consists of the following tasks:

- Develop corrective action objectives.

- Identify corrective action alternative screening criteria.

- Develop corrective action alternatives.

- Perform detailed and comparative evaluations of the corrective action alternatives in relation to the corrective action objectives and screening criteria.

- Recommend and justify a preferred corrective action alternative for the Corrective Action Site.

A corrective action investigation was conducted in September 1999, as set forth in the Corrective Action Investigation Plan for Corrective Action Unit 230: Area 22 Sewage Lagoons, Corrective Action Unit 320: Area 22 Desert Rock Airport Strainer Box, Nevada Test Site, Nevada (DOE/NV, 1999). The contaminants of concern identified above preliminary action levels are total petroleum hydrocarbons as diesel-range organics. Details regarding the investigation can be found in Appendix A of this document. 
Based on the potential exposure pathways, the following corrective action objectives have been identified for Corrective Action Unit 230/320:

- Prevent or mitigate inadvertent exposure to subsurface debris and contaminated soil at concentrations exceeding the preliminary action level as defined in the corrective action investigation plan.

- Prevent adverse impacts to groundwater quality.

Based on the review of existing data, future use, and current operations at the Nevada Test Site, the following alternatives were developed for consideration at the Area 22 Sewage Lagoons:

- Alternative 1 - No Further Action

- Alternative 2 - Closure in Place with Administrative Controls

- Alternative 3 - Excavation and Removal

The corrective action alternatives were evaluated based on four general corrective action standards and five remedy selection decision factors. Based on the results of this evaluation, the preferred alternative for Corrective Action Unit 230/320 is clean closure by Alternative 3, Excavation and Removal.

The preferred corrective action alternative was evaluated on technical merit; focusing on performance, reliability, feasibility, and safety. Alternative 3, Excavation and Removal was judged to meet all requirements for the technical components evaluated. The alternative meets all applicable state and federal regulations for closure of the site and will significantly reduce the potential future exposure pathways to the contaminated soil at the Area 22 Sewage Lagoons site. During corrective action implementation, this alternative may potentially present low risks to site workers. Therefore, appropriate health and safety procedures will be developed and implemented. 


\subsection{Introduction}

This Corrective Action Decision Document (CADD) has been prepared for Corrective Action Unit 230, Area 22 Sewage Lagoons and Corrective Action Unit 320, Area 22 Desert Rock Airport Strainer Box, Nevada Test Site, Nevada, in accordance with the Federal Facility Agreement and Consent Order (FFACO, 1996). These Corrective Action Units (CAUs) will be collectively referred to as Corrective Action Unit 230/320 or as the Area 22 Sewage Lagoons site. The Area 22 Sewage Lagoons site is comprised of two Corrective Action Sites (CASs), 22-03-01, Sewage Lagoon and 22-99-01, Strainer Box and also includes a buried Imhoff Tank, sludge bed, and associated sewer piping.

Corrective Action Unit 230/320 is located at the Nevada Test Site (NTS) in Area 22, southwest of Mercury, Nevada. The NTS is approximately 65 miles (mi) northwest of Las Vegas, Nevada. The Area 22 Sewage Lagoons site was used for sanitary sewage disposal at the historic Camp Desert Rock facility which was operational primarily from 1951 to 1958 (Figure 1-1).

\subsection{Purpose}

This CADD identifies and provides a rationale for the selection of a recommended corrective action alternative for CAU 230/320. The need for evaluation of corrective action alternatives is based on process knowledge and the results of investigative activities conducted in accordance with the Corrective Action Investigation Plan (CAIP) for Corrective Action Unit 230: Area 22 Sewage Lagoons and Corrective Action Unit 320: Area 22 Desert Rock Airport Strainer Box, Nevada Test Site, Nevada (DOE/NV, 1999).

\subsection{Scope}

The scope of this CADD consists of the following:

- Develop corrective action objectives.

- Identify corrective action alternative screening criteria.

- Develop corrective action alternatives. 


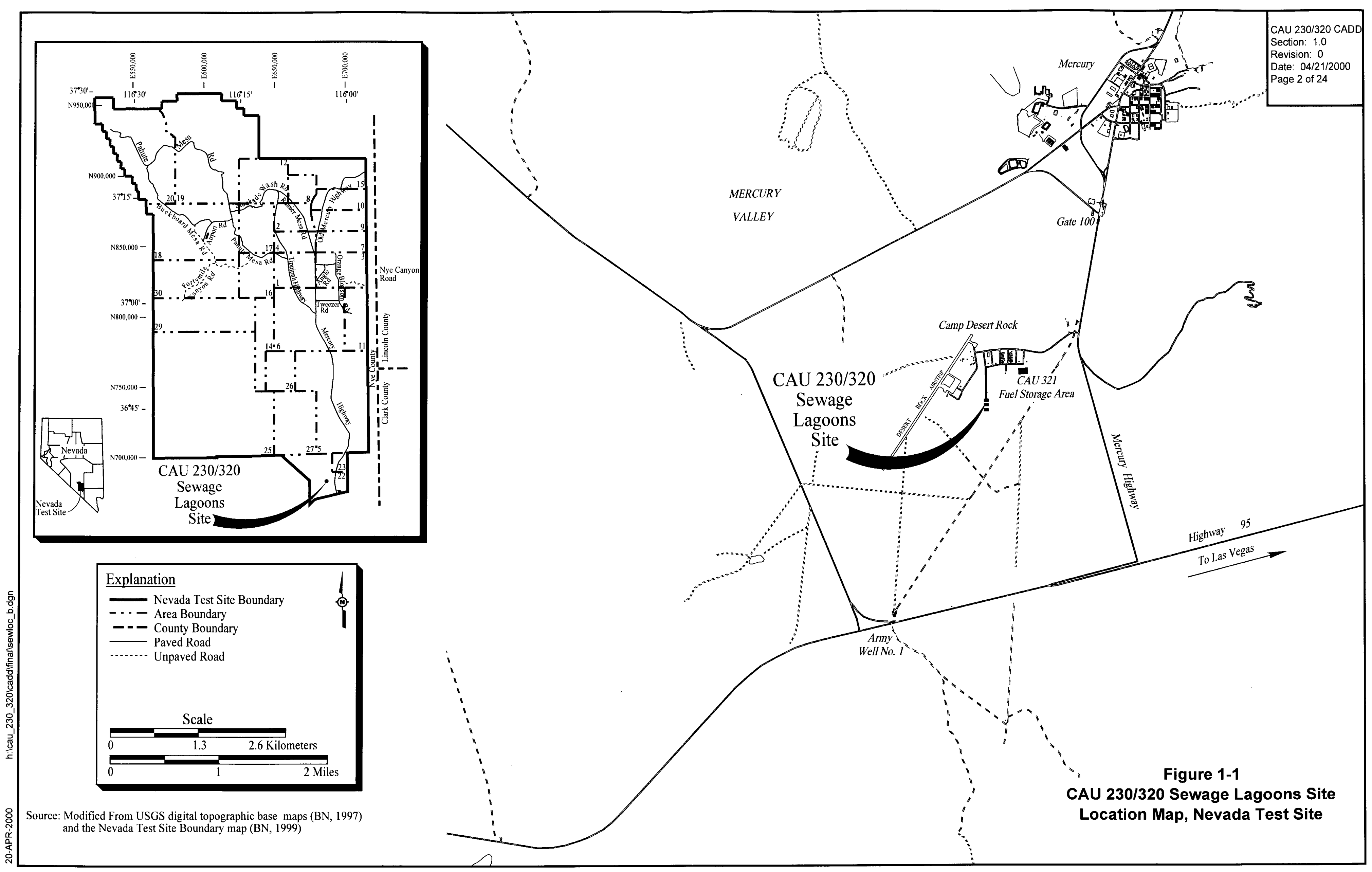


- Perform detailed and comparative evaluations of corrective action alternatives in relation to corrective action objectives and screening criteria.

- Recommend and justify a preferred corrective action alternative for the CAU.

\section{$1.3 \quad C A D D$ Contents}

This CADD is divided into the following sections:

Section 1.0 - Introduction: summarizes the purpose, scope, and contents of this CADD.

Section 2.0 - Corrective Action Investigation Summary: summarizes the investigation field activities, the results of the investigation, and the need for corrective action.

Section 3.0 - Evaluation of Alternatives: documents steps taken to determine a preferred corrective action alternative.

Section 4.0 - Recommended Alternative: presents the preferred corrective action alternative and the rationale for its selection based on the corrective action objectives and alternative screening criteria.

Section 5.0 - References: provides a list of all referenced documents.

Appendix A: Corrective Action Investigation Report for CAU 230: Area 22 Sewage Lagoons and CAU 320: Area 22 Desert Rock Airport Strainer Box, NTS, NV

Appendix B: Cost Estimates

Appendix C: Evaluation of Risk

Appendix D: Manhole Investigation/CADD Photos

All work was performed in accordance with the following documents:

- Corrective Action Investigation Plan for Corrective Action Unit 230: Area 22 Sewage Lagoons and Corrective Action Unit 320: Area 22 Desert Rock Airport Strainer Box, Nevada Test Site, Nevada (DOE/NV, 1999)

- Industrial Sites Quality Assurance Project Plan (DOE/NV, 1996b)

- FFACO (1996)

- Project Management Plan (DOE/NV, 1994) 


\subsection{Corrective Action Investigation Summary}

The following sections describe and summarize the results of the investigation activities conducted at the CAU 230/320 site. For detailed investigation results, please refer to Appendix A.

\section{$2.1 \quad$ Investigation Activities}

From September 20 through 23, 1999, corrective action investigation activities were performed at CAU 230/320 as set forth in the CAIP (DOE/NV, 1999). The purpose of the investigation was as follows:

- Identify the presence of contaminants of potential concern (COPCs) at the CAU.

- Determine the vertical and lateral extent of COPCs.

- Provide sufficient information and sample analytical data from which corrective action alternatives may be developed and evaluated in this CADD for the CAU.

The investigation activities performed are summarized below:

- Prior to soil sampling, a magnetic survey was conducted to assist in the identification of the sludge pipe that conveyed sludge from the Imhoff Tank to the sludge bed.

- Collected a total of 38 near-surface and subsurface soil samples from 19 locations using a Geoprobe Macrocore ${ }^{\circledR}$ sampler and a backhoe. Samples were collected as specified in the CAIP (DOE/NV, 1999) except at locations where caliche was encountered. At those locations, the maximum sampling depth was reduced to that which was attainable.

- Field-screened soil samples for volatile organic compounds (VOCs) and total petroleum hydrocarbons (TPH).

- Field-surveyed soil samples for alpha/beta emitting radionuclides.

- Submitted 38 samples for laboratory analysis. The number and location of samples selected for laboratory analysis were based on field-screening results.

- Twenty-nine soil samples collected outside the sludge bed area (22SL001A through 22SL017B) were submitted for semivolatile organic compounds (SVOC) analysis only. 
- Seven soil samples within the sludge bed area (22SL018A through 22SL019D) were submitted for total VOC, total SVOC, and TPH-gasoline and diesel-range organics analyses.

- Two soil samples (22SL018D and field duplicate sample 22S1018F) from the deepest sample location (10.5 feet [ft] below ground surface [bgs]) in trench/test pit 22SL018, within the sludge bed area, were collected and submitted for analyses of total VOCs, total SVOC, TPH-gasoline and diesel-range organics, Toxicity Characteristic Leaching Procedure (TCLP) VOCs, TCLP SVOCs, TCLP Resource Conservation and Recovery Act (RCRA) metals, TCLP pesticides, and gamma emitters for waste management purposes.

- On March 14 and 15, 2000, at the request of NDEP, each of the manholes associated with the septic system leading to the Imhoff Tank was inspected to determine the presence of any residual solids/sludges. The manholes are identified by number in Figure D-1 and described in Table D-1 of Appendix D.

\subsection{Results}

The corrective action investigation analytical results indicated:

- All total VOC, SVOC, and TPH as gasoline-range organics results were below the preliminary action levels (PALs) stated in the CAIP (DOE/NV, 1999).

- Three samples from the sludge bed area have TPH as diesel-range organics concentrations ranging from 150 milligrams per kilogram $(\mathrm{mg} / \mathrm{kg}$ ) to $580 \mathrm{mg} / \mathrm{kg}$ and are above the Nevada Department of Environmental Protection (NDEP) action level of $100 \mathrm{mg} / \mathrm{kg}$.

- The minimum reporting limits were not exceeded for TCLP VOC, TCLP SVOC, TCLP RCRA metals, or TCLP pesticides (DOE/NV, 1999)

- $\quad$ Results for gamma-emitting radionuclides were below the PALs stated in the CAIP (DOE/NV, 1999)

- Excavation of the sludge bed area uncovered asphalt debris and soil with four yellow and black-stripped safety poles and strands of barbed wire. The debris did not extend beyond approximately $9 \mathrm{ft}$ bgs. The results of the magnetic survey indicate the area of the debris is approximately 50 X $50 \mathrm{ft}$.

- Inspection of each of the manholes associated with the septic system leading to the Imhoff Tank revealed trace amounts of soil particles and rodent excreta. Solids found in the manholes appear to be incidental to post operations system decay and passive influent, and therefore, not contaminated by operational discharges to the system. Sludges were not present in any of the manholes inspected. Appendix D contains additional information on this subject matter. 
The details of the methods used and results found during the investigation are presented in Appendix A. Based on these results, the presence and extent of contaminants of concern (COCs) at CAU 230/320 have been adequately identified to develop and evaluate corrective action alternatives.

\subsection{Need for Corrective Action}

Investigation activities provided sufficient information to establish a need for corrective action at the sludge bed area. Analytes detected during the corrective action investigation were evaluated against PALs to determine COCs for CAU 230/320. The only COC identified is TPH as diesel-range organics at the sludge bed area that exceeded the established PAL. No other COCs were identified at the site above PALs specified in the CAIP. The following components of Area 22 Sewage Lagoons site will be addressed for corrective action in the following manner:

- Sludge Bed Area: The sludge bed area exhibits characteristics of a Class III landfill because of the disposal and burial of asphalt and other debris in the sludge bed between September 1980 and March 1982. However, the disposal occurred prior to the enactment of Nevada Administrative Code [NAC] regulations (effective September 2, 1992), Class III Sites (NAC 444.731 through NAC 444.747) and, therefore, does not need to meet these requirements (NAC, 1999b). However, corrective action alternatives will be evaluated to prevent or mitigate human exposure to COC-contaminated soil and debris. The corrective actions will include activities to repair and/or maintain a protective soil cover at this site.

- Strainer Box: The strainer box is an open concrete vault with an approximate 10-inches (in.) diameter vitrified clay pipe running horizontally through it. This piping connects the drains from the Camp Desert Rock facility with the Imhoff Tank. No COCs were identified above PALs for the strainer box area so no corrective actions are required for the site. However, best management practices should include those which protectively cover the open concrete vault and prevent or mitigate the accumulation of water in the existing piping.

- Sewer Piping: Sewer piping throughout the facility connects to the strainer box and then to the Imhoff Tank. Best management practices for the site should include those which prevent or mitigate the accumulation of water, soil, and debris in the existing piping as was identified during the manhole inspection activities. No COCs are assumed to be contained in the piping because no COCs were identified during the investigation that are the result of sewage system disposal practices. The only COC identified during the investigation was within the sludge bed area and contamination is associated with the disposal of asphalt debris.

- Buried Imhoff Tank: The Imhoff Tank was filled with dirt and vegetation has reestablished. However, some soil in the Imhoff Tank area is being eroded. No COCs were identified above PALs for the Imhoff Tank area. Best management practices for the site should include stabilization of the soil to prevent potential for further subsidence and/or erosion. 
- Sewage Lagoons: No COCs were identified above PALs for the sewage lagoon area. No further action is recommended for the sewage lagoons.

Potential corrective actions will be identified and evaluated in this CADD to ensure worker, public, and environmental protection against potential hazards associated with exposure to TPH as diesel-range organics and subsurface debris in the sludge bed area only in accordance with the NAC 445A.227, "Contamination of Soil" (NAC, 1999c). The volume of impacted media is approximately 556 cubic yards. Site-specific characteristics that may constrain remedial actions include overhead utilities, Desert Rock Airport activities, and the adjacent sewage lagoons. 


\subsection{Evaluation of Alternatives}

The purpose of this section is to present the corrective action objectives for CAU 230/320, describe the general standards and decision factors used to screen the corrective action alternatives, and develop and evaluate a set of corrective action alternatives that could be used to meet the corrective action objectives.

\subsection{Corrective Action Objectives}

The corrective action objectives are media-specific goals for protecting human health and the environment. Based on the potential exposure pathways (Section 3.1.2), the following corrective action objectives have been identified for CAU 230/320:

- Prevent or mitigate inadvertent exposure to subsurface debris and COC-contaminated soil and debris at concentrations exceeding the PAL as defined in the CAIP (DOE/NV, 1999).

- Prevent adverse impacts to groundwater quality.

\subsubsection{Contaminants of Concern}

Contaminants of potential concern were determined in the Data Quality Objective (DQO) process as listed in the CAIP (DOE/NV, 1999). Analytical results obtained from the corrective action investigation were evaluated to determine if COPCs were detected above PALs. If the PALs are exceeded, those contaminants are considered to be COCs for CAU 230/320 that may require corrective action. Based on the results of this evaluation, only TPH as diesel-range organics (in the sludge bed area only) was identified for this site.

\subsubsection{Potential Exposure Pathways}

As identified in the Nevada Test Site Resource Management Plan (DOE/NV, 1998) and the NTS Environmental Impact Statement (DOE/NV, 1996a), the future use for the site is designated for the development of a solar power generation facility, light industrial equipment, and commercial manufacturing capability. As part of the CAIP (DOE/NV, 1999), a conceptual model for CAU 230/320 was developed which identified the potential exposure mechanism as disturbance of contaminated soil by site workers. This implies a potential exposure pathway through ingestion and 
inhalation of, and dermal contact with contaminated soil under industrial scenarios. Site workers could potentially be exposed to contaminated soil during excavation activities associated with general maintenance or through construction and maintenance of underground utilities. Contaminant migration to groundwater is not considered to be an exposure pathway because of the depth to groundwater (about 800 to 1,100 ft bgs) (Winograd and Thordarson, 1975), the arid environment, surficial geology, and the lack of a sufficient driving force.

\subsection{Screening Criteria}

The screening criteria used to evaluate and select the preferred corrective action alternatives are identified in the U.S. Environmental Protection Agency (EPA) Guidance on RCRA Corrective Action Decision Documents (EPA, 1991) and the Final RCRA Corrective Action Plan (EPA, 1994).

Corrective action alternatives will be evaluated based on four general corrective action standards and five remedy selection decision factors. All corrective action alternatives must meet the general standards to be selected for evaluation using the remedy selection decision factors.

The general corrective action standards are as follows:

- Protection of human health and the environment

- Compliance with media cleanup standards

- Control the source(s) of the release

- Compliance with applicable federal, state, and local standards for waste management

The remedy selection decision factors are as follows:

- Short-term reliability and effectiveness

- Reduction of toxicity, mobility, and/or volume

- Long-term reliability and effectiveness

- Feasibility

- Cost

\subsubsection{Corrective Action Standards}

The following text describes the corrective action standards used to evaluate the corrective action alternatives: 


\section{Protection of Human Health and the Environment}

Protection of human health and the environment is a general mandate of the RCRA statute (EPA, 1994). This mandate requires that the corrective action include any protective measures that are needed. These measures may or may not be directly related to media cleanup, source control, or management of wastes. The corrective action alternatives are evaluated for the ability to meet corrective action objectives as defined in Section 3.1.

\section{Compliance with Media Cleanup Standards}

Each corrective action alternative must meet the proposed media cleanup standards as set forth in applicable state and federal regulations and as specified in the CAIP (DOE/NV, 1999). For CAU 230/320, the EPA's Region 9 Preliminary Remediation Goals (EPA, 1998), which are derived from the Integrated Risk Information System, are the basis for establishing the PALs for chemical contaminants in accordance with NAC 445A.2272, (NAC, 1999c). The PAL for petroleum substances in soil is $100 \mathrm{mg} / \mathrm{kg}$ in accordance with NAC 445A.2272, (NAC, 1999c). The PALs for radiological contaminants are based on background concentrations. Laboratory results above PALs indicate the presence of COPCs at levels that may require corrective action.

\section{Control the Source(s) of the Release}

An objective of a corrective action remedy is to stop further environmental degradation by controlling or eliminating additional releases that may pose a threat to human health and the environment. Unless source control measures are taken, efforts to clean up releases may be ineffective or, at best, will essentially involve a perpetual cleanup. Therefore, each corrective action alternative must use an effective source control program to ensure the long-term effectiveness and protectiveness of the corrective action.

\section{Comply with Applicable Federal, State, and Local Standards for Waste Management}

During implementation of any corrective action alternative, all waste management activities must be conducted in accordance with applicable state and federal regulations (e.g., Nevada Revised Statutes [NRS] 459.400 - 459.600, "Disposal of Hazardous Waste” [NRS, 1996]; 40 Code of Federal Regulations [CFR] 260 - 282, "RCRA Regulations" (CFR, 1998); NAC 444, "Sanitation" (NAC, 1999a); and NAC 459.9974, "Disposal and Evaluation of Contaminated Soil” [NAC, 1998]). The requirements for management of the waste, if any, derived from the corrective action will be 
determined based on applicable state and federal regulations, field observations, process knowledge, characterization data, and data collected and analyzed during corrective action implementation. Administrative controls (e.g., decontamination procedures and corrective action strategies) will minimize waste generated during site corrective action activities. Decontamination activities will be performed in accordance with approved procedures.

\subsubsection{Remedy Selection Decision Factors}

The following text describes the remedy selection decision factors used to evaluate the corrective action alternatives:

\section{Short-Term Reliability and Effectiveness}

Each corrective action alternative must be evaluated with respect to its effects on human health and the environment during implementation of the corrective action. The following factors will be addressed for each alternative:

- Protection of the community from potential risks associated with implementation such as fugitive dusts, transportation of hazardous materials, and explosion

- Protection of workers during implementation

- Environmental impacts that may result from implementation

- The amount of time until the corrective action objectives are achieved

\section{Reduction of Toxicity, Mobility, and/or Volume}

Each corrective action alternative must be evaluated for its ability to reduce the toxicity, mobility, and/or volume of the contaminated media. Reduction in toxicity, mobility, and/or volume refers to changes in one or more characteristics of the contaminated media by the use of corrective measures that decrease the inherent threats associated with that media.

\section{Long-Term Reliability and Effectiveness}

Each corrective action alternative must be evaluated in terms of risk remaining at the CAU after the corrective action alternative has been implemented. The primary focus of this evaluation is on the extent and effectiveness of the controls that may be required to manage risk posed by treatment residuals and/or untreated wastes. 


\section{Feasibility}

The feasibility criterion addresses the technical and administrative feasibility of implementing a corrective action alternative and the availability of services and materials needed during implementation. Each corrective action alternative must be evaluated for the following criteria:

- Construction and Operation refers to the feasibility of implementing a corrective action alternative given the existing set of waste and site-specific conditions.

- Administrative Feasibility refers to the administrative activities needed to implement the corrective action alternative (e.g., permits, public acceptance, rights-of-way, off-site approval).

- Availability of Services and Materials refers to the availability of adequate off-site and on-site treatment, storage capacity, disposal services, necessary technical services and materials, and prospective technologies for each corrective action alternative.

\section{Cost}

Costs for each alternative are estimated for comparison purposes only. The cost estimate for each corrective action alternative includes both capital and operation and maintenance costs, as applicable.

The following is a brief description of each component:

- Capital Costs: These costs include both direct and indirect costs. Direct costs may consist of materials, labor, mobilization, demobilization, site preparation, construction materials, equipment purchase and rental, sampling and analysis, waste disposal, and health and safety measures. Indirect costs include such items as engineering design, permits and/or fees, start-up costs, and any contingency allowances.

- Operation and Maintenance: These costs include labor, training, sampling and analysis, maintenance materials, utilities, and health and safety measures.

Cost summaries for this CADD are provided in Appendix B.

\subsection{Development of Corrective Action Alternatives}

This section identifies and briefly describes the viable corrective action alternative technologies considered for the affected media. Based on the review of existing data, future use, and current 
operations at the NTS, the following alternatives have been developed for consideration at CAU 230/320:

- Alternative 1 - No Further Action

- Alternative 2 - Closure in Place with Administrative Controls

- Alternative 3 - Excavation and Removal

Other alternatives such as bioremediation were considered; however, these alternatives were not determined viable.

The following is an evaluation of NAC 445A.227(2), (a-k) (NAC, 1999c):

a. In Mercury Valley (Area 22), the depth to groundwater is approximately 800 to $1,100 \mathrm{ft}$ bgs (Winograd and Thordarson, 1975; Robie et al., 1995). The depth to groundwater for two wells near the CAU 230/320 site is $785 \mathrm{ft}$ at Army Well 1 and 1,164 ft at SM-23-1, a monitoring well for the Mercury sewage treatment plant (Wood, 1999; USGS, 1999). The field screening and analytical data indicate that the COC-contaminated soil and debris are confined primarily from between 3 to $9 \mathrm{ft}$ bgs in the sludge bed area. Due to the depth to groundwater and the limited concentration and relatively minor extent of the COC, groundwater is not expected to be impacted at this site.

b. The distance to the nearest water-supply well, Army Well 1, is approximately 2 mi southwest of the Area 22 Sewage Lagoons site (LaCamera and Westenberg, 1994). Army Well 1 is primarily used as a backup water supply for Mercury, Nevada. The groundwater flow direction is generally to the southwest (Laczniak et al., 1996).

c. Surficial deposits at the Area 22 Sewage Lagoons site consists of poorly-sorted silt, sand, abundant gravel, and some cobbles overlying a layer of caliche that occurs at approximately 8.5 to $10.5 \mathrm{ft}$ bgs. Field screening and analytical data indicate that the COC-contaminated soil and debris are confined primarily between 3 to $9 \mathrm{ft}$ bgs in the sludge bed area.

d. Average annual precipitation for valleys in the South-Central Great Basin ranges from 3 to 6 in. (Winograd and Thordarson, 1975). Annual mean precipitation data for the Desert Rock weather station, located near the CAU 230/320 site, for the time period from 1961 to 1990, is 5.68 in. (Wood, 1999). Annual evaporation is roughly 5 to 25 times the annual precipitation (Winograd and Thordarson, 1975). The high evaporation and low precipitation rates create a negative water balance for the area; therefore, no driving force associated with precipitation is available to mobilize the COC vertically. Localized heavy precipitation events are not expected to mobilize the $\mathrm{COC}$ because analytical results indicate that contamination occurs between approximately 3 to $9 \mathrm{ft}$ bgs. 
e. The type of regulated substance released at the site is TPH as diesel-range organics. The COC concentration ranges from 150 to $580 \mathrm{mg} / \mathrm{kg}$.

f. The lateral extent of COC contamination is within the sludge bed area of the CAU 230/320 with an areal extent of approximately 50 by $50 \mathrm{ft}$. The vertical extent of COC-contaminated soil and debris is near the ground surface generally between 3 to $9 \mathrm{ft}$ bgs. The volume of impacted media is estimated to be 556 cubic yards.

g. Presently, CAU 230/320 is located within Area 22, a general use zone, located within the NTS, a government-controlled facility (DOE/NV, 1998). Activities within Area 22 require prior permission by the NTS which is a restricted area and unauthorized personnel are not allowed at the facility. Future use for the CAU 230/320 area is designated for light industrial use (e.g., development of a solar energy power-generation facility, industrial park, or for commercial manufacturing) (DOE/NV, 1996a; DOE/NV, 1998).

h. Preferred routes of migration are vertical due to downward mobility, and lateral due to run on/run off and inadvertent intrusion. The potential for migration is limited by the following factors:

- Caliche is present at the site below the sludge bed and sewage lagoon areas at approximately 8.5 to $10.5 \mathrm{ft}$ below the topographic surface. The caliche, because of its density and composition, can behave as a barrier or as a relatively impermeable layer for the type of COC-contamination identified thus limiting downward migration.

- The soil within the investigation area is not saturated and depth-to-water at the nearest well (Army Well 1) is approximately $785 \mathrm{ft}$ bgs.

- The stable asphalt matrix which confines the COC.

- Arid environment is not conducive to vertical migration of the COC because of high evaporation and low precipitation rates which creates a negative water balance; therefore, no driving force associated with precipitation is available to mobilize the COC vertically.

- Investigation indicated no downward migration of COC from release point to the underlying sludge bed layer since release. The COC-contaminated soil and debris were placed in the sludge bed area around 1981 based on aerial photographs.

- Lateral migration is limited because analytical results show that the COC-contaminated soil and debris are buried approximately $3 \mathrm{ft}$ bgs and are generally protected from ephemeral flooding and inadvertent intrusion. 
i. Structures and impediments that may impact potential remediation activities at the sludge bed area are overhead utilities, Desert Rock Airport activities, and adjacent sewage lagoons.

j. The potential for a hazard related to fire, vapor, or explosion is virtually nonexistent for the $\mathrm{COC}$ at the CAU.

k. No other site-specific factors are known at this time.

Based on this evaluation, impacts to groundwater are not expected. Therefore, groundwater monitoring is not proposed for this site and is not considered an element of the alternatives.

\subsubsection{Alternative 1 - No Further Action}

Under the No Further Action Alternative no corrective actions will be implemented. This alternative is a baseline case with which to compare and assess the other corrective action alternatives and their ability to meet the corrective action standards. For the sludge bed area, the No Further Action Alternative does not meet the corrective action objectives because no actions are taken to prevent the inadvertent exposure to the subsurface COC-contaminated soil and debris. This alternative will not be compared to the other alternatives using the selection decision factors.

\subsubsection{Alternative 2 - Closure in Place with Administrative Controls}

Alternative 2 consists of closure in place with administrative controls. Administrative controls would consist of use restrictions to prevent intrusive activities. Administrative controls are used to prevent inadvertent contact with COC-contaminated soil and debris. Signage can also be used to further restrict access to the contaminated area. The future use of this site would be restricted from any activity that would alter or modify the containment control unless appropriate concurrence was obtained from the NDEP.

Administrative controls are commonly used and can effectively eliminate potential exposure pathways. Administrative controls are effective because the NTS, including CAU230/320 is a restricted access facility. The implementation of administrative controls requires the coordination of all entities at a facility to ensure that the restrictions are enforced. Under Alternative 2, geotechnical sampling will be conducted to establish soil permeability. Low areas within the sludge bed cover will be backfilled with clean soil from a nearby location (if necessary). The soil cover will be compacted 
to ensure the permeability is less than that of the surrounding soil. The area should also be graded to prevent run on.

\subsubsection{Alternative 3 - Excavation and Removal}

Alternative 3 consists of the removal of COC-contaminated soil and debris with concentrations greater than the PAL within the sludge bed area. All excavated material will be disposed of at an appropriate disposal facility. The excavated areas will be returned to surficial conditions compatible with existing operations.

The COC-contaminated soil and debris will be excavated to an approximate depth of $9 \mathrm{ft}$ bgs within the vicinity of the sludge bed area, as necessary (Figure A.2-1). Activities will include excavation, confirmatory sampling, and proper disposal of an estimated volume of 556 cubic yards of contaminated soil. Confirmatory sampling will be performed at the excavation walls and will be analyzed for TPH as diesel-range organics. This will ensure the removal of COC-contaminated soil and debris at concentrations exceeding the PAL. The excavated area will be backfilled with clean soil from a nearby location and compacted. The surface will be graded for consistency with surrounding topography.

There are no implied administrative controls under Alternative 3. The Area 22 Sewage Lagoons will be closed as described in this section and in accordance with NAC 445A (NAC, 1999c).

\subsection{Evaluation and Comparison of Alternatives}

The general corrective action standards and the remedy selection decision factors described in Section 3.2 were used to conduct detailed and comparative analyses of each corrective action alternative. The advantages and disadvantages of each alternative were assessed to select a preferred alternative for CAU 230/320. Table 3-1 presents a summary of the detailed analysis of the alternatives. Table 3-2 presents the comparative analysis of alternatives. Cost summaries are provided in Appendix B. 
Table 3-1

Detailed Evaluation of Alternatives

(Page 1 of 3 )

\begin{tabular}{|c|c|c|c|}
\hline Evaluation Criteria & No Further Action & $\begin{array}{c}\text { Alternative } 2 \\
\text { Closure in Place with } \\
\text { Administrative Controls }\end{array}$ & $\begin{array}{c}\text { Alternative } 3 \\
\text { Excavation and Removal }\end{array}$ \\
\hline \multicolumn{4}{|c|}{ Closure Standards } \\
\hline $\begin{array}{l}\text { Protection of Human } \\
\text { Health and the } \\
\text { Environment }\end{array}$ & $\begin{array}{l}\text { - Does not meet corrective } \\
\text { action objective of } \\
\text { preventing or mitigating } \\
\text { inadvertent exposure to } \\
\text { subsurface } \\
\text { contamination. } \\
\text { - NAC 445A.227(2)(a-k) } \\
\text { analysis shows the } \\
\text { contaminant is not } \\
\text { expected to impact } \\
\text { groundwater } \\
\text { No worker exposure } \\
\text { associated with } \\
\text { implementation }\end{array}$ & 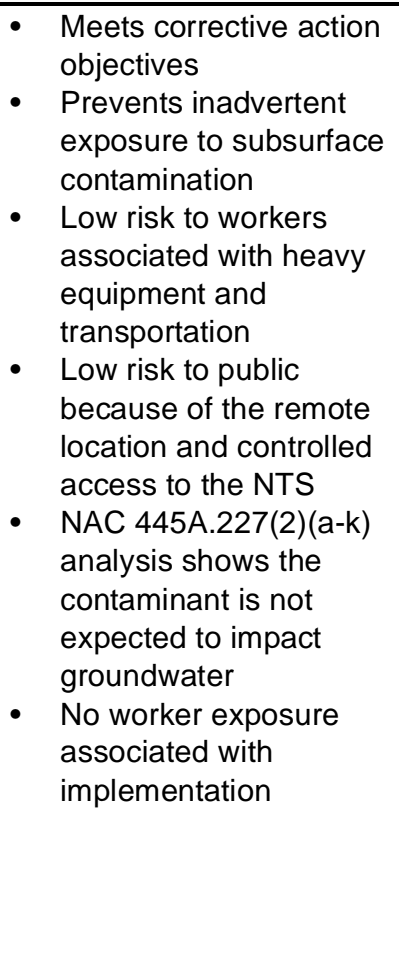 & 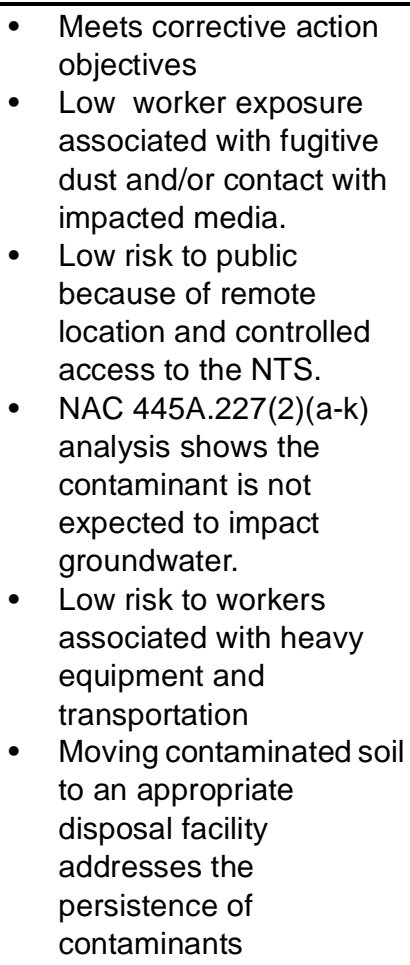 \\
\hline $\begin{array}{l}\text { Compliance with } \\
\text { Media Cleanup } \\
\text { Standards }\end{array}$ & $\begin{array}{l}\text { Does not comply with } \\
\text { media clean up } \\
\text { standards } \\
\text { NAC 445A.227(2)(a-k) } \\
\text { analysis shows the } \\
\text { contaminant is not } \\
\text { expected to impact } \\
\text { groundwater }\end{array}$ & $\begin{array}{l}\text { Complies with media } \\
\text { cleanup standards by } \\
\text { controlling exposure } \\
\text { pathways } \\
\text { NAC 445A.227(2)(a-k) } \\
\text { analysis shows the } \\
\text { contaminant is not } \\
\text { expected to impact } \\
\text { groundwater }\end{array}$ & $\begin{array}{l}\text { Complies with media } \\
\text { cleanup standards } \\
\text { because } \\
\text { COC-contaminated soil } \\
\text { and debris exceeding the } \\
\text { PAL will be excavated } \\
\text { and disposed of at an } \\
\text { appropriate facility. } \\
\text { Removal of COC with } \\
\text { concentrations } \\
\text { exceeding the PAL and } \\
\text { verified by confirmation } \\
\text { sampling. } \\
\text { NAC } 445 A .227(2)(a-k) \\
\text { analysis shows the } \\
\text { contaminant is not } \\
\text { expected to impact } \\
\text { groundwater }\end{array}$ \\
\hline
\end{tabular}


Table 3-1

Detailed Evaluation of Alternatives

(Page 2 of 3 )

\begin{tabular}{|c|c|c|c|}
\hline Evaluation Criteria & No Further Action & $\begin{array}{c}\text { Alternative } 2 \\
\text { Closure in Place with } \\
\text { Administrative Controls }\end{array}$ & $\begin{array}{c}\text { Alternative } 3 \\
\text { Excavation and Removal }\end{array}$ \\
\hline $\begin{array}{l}\text { Control the Source(s) } \\
\text { of Release }\end{array}$ & $\begin{array}{l}\text { The source (disposal of } \\
\text { COC-contaminated soil } \\
\text { and debris in the sludge } \\
\text { bed area) has been } \\
\text { discontinued }\end{array}$ & $\begin{array}{l}\text { The source (disposal of } \\
\text { cOC-contaminated soil } \\
\text { and debris in the sludge } \\
\text { bed area) has been } \\
\text { discontinued }\end{array}$ & $\begin{array}{l}\text { The source (disposal of } \\
\text { COC-contaminated soil } \\
\text { and debris in the sludge } \\
\text { bed area) has been } \\
\text { discontinued }\end{array}$ \\
\hline $\begin{array}{l}\text { Comply with } \\
\text { Applicable Federal, } \\
\text { State, and Local } \\
\text { Standards for Waste } \\
\text { Management }\end{array}$ & - No waste generated. & - No waste generated. & $\begin{array}{l}\text { All waste generated } \\
\text { (primarily } \\
\text { COC-contaminated soil } \\
\text { and debris, and } \\
\text { disposable personal } \\
\text { protective equipment) will } \\
\text { be handled and disposed } \\
\text { of in accordance with } \\
\text { applicable standards. }\end{array}$ \\
\hline
\end{tabular}

\begin{tabular}{|c|c|c|c|}
\hline \multicolumn{4}{|c|}{ Remedy Selection Decision Factors } \\
\hline $\begin{array}{l}\text { Short-Term Reliability } \\
\text { and Effectiveness }\end{array}$ & - $\quad$ Not evaluated & $\begin{array}{l}\text { - Public protected by } \\
\text { remote location and NTS } \\
\text { site access controls } \\
\text { Environmental impacts } \\
\text { are not anticipated due to } \\
\text { implementation. } \\
\text { Appropriate measures } \\
\text { will be taken at the site to } \\
\text { protect desert tortoises } \\
\text { during implementation. } \\
\text { Implementation should } \\
\text { not require an extended } \\
\text { period of time. } \\
\text { Low risk to workers } \\
\text { associated with heavy } \\
\text { equipment and } \\
\text { transportation }\end{array}$ & $\begin{array}{l}\text { - Low worker exposure } \\
\text { associated with fugitive } \\
\text { dust and/or contact with } \\
\text { impacted media. } \\
\text { Public protected by } \\
\text { remote location and NTS } \\
\text { site access controls. } \\
\text { Environmental impacts } \\
\text { are not anticipated due to } \\
\text { implementation. } \\
\text { Appropriate measures } \\
\text { will be taken at the site to } \\
\text { protect desert tortoises } \\
\text { during implementation. } \\
\text { Implementation should } \\
\text { not require an extended } \\
\text { period of time. } \\
\text { Low risk to workers } \\
\text { associated with heavy } \\
\text { equipment and } \\
\text { transportation }\end{array}$ \\
\hline
\end{tabular}


Table 3-1

Detailed Evaluation of Alternatives (Page 3 of 3)

\begin{tabular}{|c|c|c|c|}
\hline Evaluation Criteria & No Further Action & $\begin{array}{c}\text { Alternative } 2 \\
\text { Closure in Place with } \\
\text { Administrative Controls }\end{array}$ & $\begin{array}{c}\text { Alternative } 3 \\
\text { Excavation and Removal }\end{array}$ \\
\hline $\begin{array}{l}\text { Reduction of Toxicity, } \\
\text { Mobility, and/or } \\
\text { Volume }\end{array}$ & - Not evaluated & $\begin{array}{l}\text { Volume and toxicity } \\
\text { levels of contamination } \\
\text { would remain essentially } \\
\text { unchanged at the site. } \\
\text { The mobility of remaining } \\
\text { subsurface } \\
\text { contamination is } \\
\text { significantly reduced by } \\
\text { administrative controls } \\
\text { the arid environment, and } \\
\text { the physical } \\
\text { characteristics of the } \\
\text { coC. }\end{array}$ & $\begin{array}{l}\text { Clean closure would } \\
\text { significantly reduce } \\
\text { associated toxicity, } \\
\text { mobility, and volume of } \\
\text { wastes at the Area } 22 \\
\text { Sewage Lagoons site. } \\
\text { Proper disposal of the } \\
\text { waste after removal } \\
\text { would result in a } \\
\text { reduction of mobility. }\end{array}$ \\
\hline $\begin{array}{l}\text { Long-Term Reliability } \\
\text { and Effectiveness }\end{array}$ & - Not evaluated & $\begin{array}{l}\text { Controls the inadvertent } \\
\text { intrusion into the } \\
\text { remaining contaminated } \\
\text { area. } \\
\text { - Administrative controls } \\
\text { must be maintained. }\end{array}$ & $\begin{array}{l}\text { - All risk will be eliminated } \\
\text { upon completion. } \\
\text { - No maintenance } \\
\text { required. } \\
\text { - Area } 22 \text { Sewage } \\
\text { Lagoons site clean } \\
\text { closed. } \\
\text { Transferring } \\
\text { contaminated soil to an } \\
\text { appropriate disposal } \\
\text { facility addresses the } \\
\text { persistent adsorption of } \\
\text { contaminants to the soil. }\end{array}$ \\
\hline Feasibility & - Not evaluated & $\begin{array}{l}\text { - } \text { Closure of Area } 22 \\
\text { Sewage Lagoons site is } \\
\text { practicable. } \\
\text { Coordination of all } \\
\text { entities is necessary to } \\
\text { ensure compliance with } \\
\text { administrative controls to } \\
\text { prevent intrusion. }\end{array}$ & $\begin{array}{l}\text { - Closure of Area } 22 \\
\text { Sewage Lagoons site is } \\
\text { practicable. }\end{array}$ \\
\hline Cost & $\$ 0$ & $\$ 143,003$ & $\$ 89,445$ \\
\hline
\end{tabular}


Table 3-2

Comparative Evaluation of Alternatives

\begin{tabular}{|c|c|}
\hline Evaluation Criteria & Comparative Evaluation \\
\hline \multicolumn{2}{|r|}{ Closure Standards } \\
\hline $\begin{array}{l}\text { Protection of Human Health } \\
\text { and the Environment }\end{array}$ & $\begin{array}{l}\text { Alternative } 1 \text { does not meet corrective action objectives. Alternative } 2 \text { and } 3 \text { meet } \\
\text { corrective action objectives. Minimal risks are associated with these alternatives. } \\
\text { NAC } 445 A .227(2)(a-k) \text { analysis shows the contaminants are not threatening } \\
\text { groundwater. }\end{array}$ \\
\hline $\begin{array}{l}\text { Compliance with Media } \\
\text { Cleanup Standards }\end{array}$ & $\begin{array}{l}\text { Alternative } 1 \text { does not comply with media cleanup standards. Alternative } 2 \text { controls } \\
\text { access to contamination by effectively controlling exposure pathways. Alternative } 3 \\
\text { meets media cleanup standards by removing the COC at concentrations that exceed } \\
\text { the PAL and significantly reduces exposure pathways at the site. }\end{array}$ \\
\hline $\begin{array}{l}\text { Control the Source(s) of the } \\
\text { Release }\end{array}$ & $\begin{array}{l}\text { The source (disposal of COC-contaminated soil and debris in the sludge bed area) } \\
\text { has been discontinued. }\end{array}$ \\
\hline $\begin{array}{l}\text { Comply with Applicable } \\
\text { Federal, State, and Local } \\
\text { Standards for Waste } \\
\text { Management }\end{array}$ & $\begin{array}{l}\text { Alternatives } 1 \text { and } 2 \text { do not generate waste. Alternative } 3 \text { will generate waste that will } \\
\text { be handled in accordance with applicable standards. }\end{array}$ \\
\hline \multicolumn{2}{|r|}{ Remedy Selection Decision Factors } \\
\hline $\begin{array}{l}\text { Short-Term Reliability and } \\
\text { Effectiveness }\end{array}$ & Low risks are associated with Alternatives 2 and 3. \\
\hline $\begin{array}{l}\text { Reduction of Toxicity, Mobility, } \\
\text { and/or Volume }\end{array}$ & $\begin{array}{l}\text { Alternative } 2 \text { results in a reduction of mobility at CAU } 230 / 320 \text { but does not reduce } \\
\text { toxicity or volume. } \\
\text { Alternative } 3 \text { results in an immediate reduction of toxicity, mobility, and volume. }\end{array}$ \\
\hline $\begin{array}{l}\text { Long-Term Reliability and } \\
\text { Effectiveness }\end{array}$ & Residual risk is low for Alternative 2 and negligible for Alternative 3. \\
\hline Feasibility & Alternatives 2 and 3 are feasible. \\
\hline Cost & $\begin{array}{l}\text { The cost for Alternative } 1 \text { is } \$ 0 \text {. The estimated cost for Alternative } 2 \text { is } \$ 143,003 \text {. } \\
\text { The estimated cost for Alternative } 3 \text { is } \$ 89,445 \text {. }\end{array}$ \\
\hline
\end{tabular}




\subsection{Recommended Alternative}

Based on the results of the detailed and comparative analysis of the potential corrective action alternatives presented in this document, the preferred corrective action alternative selected for implementation at the Area 22 Sewage Lagoons site is Alternative 3, Excavation and Removal. Alternative 3 was chosen for the following reasons:

- It minimizes health risks by preventing public and worker access to the COC contamination at the Area 22 Sewage Lagoons site by transferring contaminated media to an appropriate disposal facility.

- It complies with standards for management of wastes because all waste will be managed in accordance with federal, state, and local requirements.

- It significantly reduces long-term risks by transferring contaminated soil to an appropriate disposal facility.

- It is easily implemented with standard construction equipment utilized for removal and transportation of contaminated soil.

- It provides the most cost-effective method for achieving protection and meeting closure requirements.

The preferred corrective action alternative was evaluated on its technical merits, focusing on performance, reliability, feasibility, and safety. The alternative was judged to meet all requirements for the technical components evaluated. The alternative meets all applicable state and federal regulations for closure of the site and will significantly reduce potential future exposure pathways to the contaminated soil at the Area 22 Sewage Lagoons site.

During corrective action implementation, this alternative may potentially present low risks to site workers. Therefore, appropriate health and safety procedures will be developed and implemented. Based on the evaluation in this CADD, clean closure of the Area 22 Sewage Lagoons site by excavation and removal is the preferred closure method. 


\subsection{References}

BN, see Bechtel Nevada.

Bechtel Nevada. 1997. "Point of Rocks Quadrangle Federal Facility Agreement and Consent Order Corrective Action Site," July 1997. Modified from the U.S. Geological Survey digital topographic maps. Las Vegas, NV.

Bechtel Nevada. 1999. Nevada Test Site Boundary Map. Memorandum from Kathleen Carlson (DOE/NV Manager) to John Mitchell (BN President and General Manager) regarding the Nevada Test Site boundary amendment, 17 December. Las Vegas, NV.

CFR, see Code of Federal Regulations.

Code of Federal Regulations. 1998. Title 40 CFR Parts 260 - 282, "RCRA Regulations."

Washington, DC: U.S. Government Printing Office.

DOE/NV, see U.S. Department of Energy, Nevada Operations Office.

EPA, see U.S. Environmental Protection Agency.

FFACO, see Federal Facility Agreement and Consent Order.

Federal Facility Agreement and Consent Order. 1996 (as amended). Agreed to by the State of Nevada, the U.S. Department of Energy, and the U.S. Department of Defense.

LaCamera, R.J., and C.L. Westenburg. 1994. Selected Ground-Water Data for Yucca Mountain Region, Southern Nevada and Eastern California, Through December 1992. Carson City, NV: U.S. Geological Survey.

Laczniak, R.J., J.C. Cole, D.A. Sawyer, and D.T. Trudeau. 1996. Summary of Hydrogeological Controls on Ground-Water Flow at the Nevada Test Site, Nye County, Nevada, U.S. Geological Survey Water-Resources Investigations Report 96-4109. Denver, CO: U.S. Geological Survey.

NAC, see Nevada Administrative Code.

Nevada Administrative Code. 1998. NAC 459.9974, "Disposal and Evaluation of Contaminated Soil." Carson City, NV.

Nevada Administrative Code. 1999a. NAC 444, "Sanitation." Carson City, NV. 
Nevada Administrative Code. 1999b. NAC 444.731, "Minimum standards: reduction or waiver of requirements" through NAC 444.747, "Miscellaneous requirements; reports, records, notification" for Class III Sites. Carson City, NV.

Nevada Administrative Code. 1999c. NAC 445A, "Water Controls.” Carson City, NV.

NRS, see Nevada Revised Statutes.

Nevada Revised Statutes. 1996. NRS 459.400-459.600, “Disposal of Hazardous Waste.” Carson City, NV.

Raytheon Services Nevada. 1992. "Road and Facility Map, Nevada Test Site," Nevada Test Site All Areas. Las Vegas, NV.

Robie, L., S. Reiner, and G. Locke. 1995. Ground-water Data for the Nevada Test Site, 1992, and for Selected Other Areas in South-Central Nevada, 1952-92, USGS-OFR-284. Denver, CO: U.S. Geological Survey.

U.S. Department of Energy, Nevada Operations Office. 1994. Project Management Plan, Rev. 0. Las Vegas, NV.

U.S. Department of Energy, Nevada Operations Office. 1996a. Final Environmental Impact Statement for the Nevada Test Site and Off-Site Locations in the State of Nevada, DOE/EIS 0243. Las Vegas, NV.

U.S. Department of Energy, Nevada Operations Office. 1996b. Industrial Sites Quality Assurance Project Plan, Nevada Test Site, Nevada, Rev. 1, DOE/NV--372. Las Vegas, NV.

U.S. Department of Energy, Nevada Operations Office. 1998. Nevada Test Site Resource Management Plan, DOE/NV--518. Las Vegas, NV.

U.S. Department of Energy, Nevada Operations Office. 1999. Corrective Action Investigation Plan for Corrective Action Unit 230: Area 22 Sewage Lagoons and Corrective Action Unit 320: Area 22 Desert Rock Airport Strainer Box, Nevada Test Site, Nevada, Rev. 0, DOE/NV--552. Las Vegas, NV.

U.S. Environmental Protection Agency. 1991. Guidance on RCRA Corrective Action Decision Documents, EPA/540/G-91/011. Washington, DC: Office of Research and Development.

U.S. Environmental Protection Agency. 1994. Final RCRA Corrective Action Plan, EPA/520-R-94-004. Washington, DC: Office of Solid Waste and Emergency Response.

U.S. Environmental Protection Agency. 1998. Memo from S.J. Smucker to PRG Table Mailing List regarding Region 9 Preliminary Remediation Goals (PRGs), 1 August. San Francisco, CA. 
USGS, see U.S. Geological Survey.

U.S. Geological Survey. 1999. Environmental Restoration (ER) Program's Wells: Depth-to-water measurements. Available from http://nevada.usgs.gov/gw-cgi/data.pl, as accessed in July 1999.

Winograd, I.J., and W. Thordarson. 1975. Hydrologic and Hydrochemical Framework, South-Central Great Basin, Nevada-California, with Special Reference to the Nevada Test Site, U.S. Geological Survey Professional Paper 712C. Washington, DC: U.S. Government Printing Office.

Wood, D.B. (U.S. Geological Survey). 1999. Communication with Juliana Herrington, SAIC regarding Army Well 1 depth-to water data and Desert Rock weather station precipitation information, 8 July. Las Vegas, NV. Depth-to-water data are available at the USGS Water Resource Division, Las Vegas, NV. Precipitation data for the Desert Rock Weather Station are available at http://nimbo.wrh.noaa.gov/Lasvegas/RTPLAS.shtml, as accessed in July 1999. 


\section{Appendix A \\ Corrective Action Investigation Report for CAU 230: Area 22 Sewage Lagoons and CAU 320: Area 22 Desert Rock Airport Strainer Box, Nevada Test Site, Nevada}




\section{A.1.0 Introduction}

This appendix presents corrective action investigation activities and analytical results for the CAU 230/320, Area 22 Sewage Lagoons (FFACO, 1996). The corrective action investigation was conducted in accordance with the Corrective Action Investigation Plan for Corrective Action Unit 230: Area 22 Sewage Lagoons and Corrective Action Unit 320: Area 22 Desert Rock Airport Strainer Box, Nevada Test Site, Nevada (DOE/NV, 1999) as developed under the FFACO (1996). For purposes of this discussion, the site will be referred to as either CAU 230/320 or the Area 22 Sewage Lagoons.

The Area 22 Sewage Lagoons were investigated because there was insufficient process knowledge to evaluate and select preferred corrective actions for potential contamination at the site. Additional information regarding the history of the Area 22 Sewage Lagoons and the planning and scope of the field investigation is included in the CAIP (DOE/NV, 1999).

\section{A.1.1 Project Objectives}

The primary objectives of the investigation were as follows:

- Identify the presence and the vertical and lateral extent of COPCs.

- Provide sufficient information and data to develop appropriate corrective action alternatives for the Area 22 Sewage Lagoons site.

The sampling strategy was developed and COPCs and sampling locations were selected during the DQO process (EPA, 1994c) and outlined in the CAIP (DOE/NV, 1999). The selection of soil sample locations for CAU 230/320 was biased to suspected worst-case areas as follows:

- Effluent channels (engineered and natural) (sample locations 22SL001 through 22SL005)

- Disturbed soil areas (berms surrounding the lagoons) (sample locations 22SL006 through 22SL009)

- $\quad$ Sewage lagoons (sample locations 22SL010 through and 22SL015)

- Soil near effluent outlet piping of the Imhoff Tank (i.e., sample location 22SL016) 
- Soil between the strainer box outlet piping and the Imhoff Tank inlet piping (sample location 22SL017)

- $\quad$ Sludge bed (sample locations 22SL018 and 22SL019)

\section{A.1.2 Report Content}

This report contains information and data in sufficient detail to support the selection of a preferred corrective action alternative in the CADD. The contents of this report are as follows:

- Section A.1.0 describes the investigation background, objectives, and the report content.

- Section A.2.0 provides information regarding the field activities and sampling methods.

- Section A.3.0 summarizes the results of the laboratory analysis from the investigation soil sampling.

- Section A.4.0 discusses the quality assurance (QA) and quality control (QC) procedures that were followed and the results of the QA/QC activities.

- Section A.5.0 is a summary of the investigation results.

- Section A.6.0 provides the cited references.

The complete field documentation and laboratory data, including Field Activity Daily Logs, Sample Collection Logs, Analysis Request/Chain of Custody Forms, laboratory certificates of analyses, analytical results, and surveillance results are retained in project files. 


\section{A.2.0 Field Investigation and Sampling Activities}

Prior to the field investigation, a magnetic survey was conducted to locate the end of the six-inch diameter metal sludge-bed pipe and to aid in verification of the presumed location of the sludge bed as determined from aerial photographs and engineering drawings. Results of the magnetic survey indicated that a portion of the metal sludge-bed pipe nearest the sludge bed location was no longer present. However, some 6-in. metal piping found lying on the ground surface at the east end of the site maybe the missing portion of sludge bed pipe. One assumption is that the piping was unearthed and broken off during grading operations on the dirt roadway north of the sludge bed area. The magnetic survey also indicated a strong magnetic response in the sludge bed area, the anomaly was approximately 50 X $50 \mathrm{ft}$. This areal size is consistent with the 1966 aerial photograph shown in Figure 2-1 of the CAIP. During the excavation of the sludge bed area, only asphalt debris and metal safety poles were found. There was no evidence of extensive amounts of metal debris in the sludge bed area.

The field investigation and sampling activities were conducted from September 20 through 23, 1999. Soil samples were collected with a Geoprobe ${ }^{\circledR}$ and backhoe between 0 to $10.5 \mathrm{ft}$ bgs. Excavation of the two sampling trench/test pit locations in the sludge bed area was not conducted to the planned maximum depth of $12 \mathrm{ft}$ bgs because caliche was encountered at 8.5 and $10.5 \mathrm{ft}$. Within the sewage lagoons, samples were only collected from the 2 to $2.5 \mathrm{ft}$ depth because caliche was encountered. The elevation of the caliche layer within the sewage lagoons is consistent with the caliche layer encountered in the sludge bed. Excavation beyond the caliche layer was not practicable. During the field investigation, soil samples not sent to the laboratory were returned to the sample location from which they were collected.

The field investigation and sampling program was managed in accordance with the requirements set forth in the CAIP (DOE/NV, 1999). All field activities were performed in accordance with an approved site-specific health and safety plan (IT, 1999). Samples were collected and documented by following approved protocols and procedures for sampling, field activity and sample collection documentation, decontamination, chain of custody, shipping, and radiation survey as indicated in the CAIP (DOE/NV, 1999). Quality control samples (e.g., field blanks, equipment rinsate blanks, trip blanks, source blanks, and field duplicates) were collected in accordance with the Industrial Sites 
Quality Assurance Project Plan (QAPP) (DOE/NV, 1996) and approved procedures. During field activities, waste minimization practices were followed according to approved procedures, including segregation of the waste by waste stream.

\section{A.2.1 Site Descriptions and Conditions}

The Area 22 Sewage Lagoons site is located at the NTS (Figure 1-1 of the CADD). The site is part of the historic Camp Desert Rock facility and has been inactive since 1958. This site is abandoned and has not been included on any water pollution control permits issued by the NDEP (NDEP, 1994; NDEP, 1997; NDEP, 1999).

The overall topography in Area 22 slopes slightly to the southwest. During the investigation, the weather conditions at the CAU 230/320 site were generally favorable, partly cloudy to sunny, with intermittent rain showers, cool to warm temperatures, and breezy at times with directional wind changes. Weather conditions did not present any major impacts to sampling activities or the field investigation schedule. A short rain delay for approximately two hours was used to package and ship samples.

Soil conditions at the site made sample collection difficult at times because of the alluvial fan material (i.e., abundant gravel and cobbles). Caliche was encountered at the sample locations within the sewage lagoons and in the sludge bed area. No sludge layer was encountered at the site.

\section{A.2.1.1 Sample Locations}

The sampling locations were biased to suspected-worse case locations where COPCs could have accumulated. For example, the biased sample locations were placed in the sewage lagoons, sludge bed, disturbed soil mounds around the lagoons, ephemeral drainages south of the lagoons, and near the piping that enters and exists the Imhoff Tank (Figure 4-1 of the CAIP). Actual sample locations are shown in Figure A.2-1. The soil sample locations for the Area 22 Sewage Lagoons were numbered 1 through 19. The soil samples were numbered 22SL001 through 22SL019 with the last two digits correlating to the sample location number. At the end of each soil sample number is a designation letter “A, B, C, or D" to indicate the depth of the sampling interval. The planned sampling depth interval " $\mathrm{A}$ " is 1 to $2 \mathrm{ft}$ and " $\mathrm{B}$ " is 3 to $4 \mathrm{ft}$ bgs for the Geoprobe ${ }^{\circledR}$ sample locations. 
The planned sampling depth interval " $\mathrm{A}$ " is $3 \mathrm{ft}$; " $\mathrm{B}$ " is $6 \mathrm{ft} \mathrm{bgs}$; " $\mathrm{C}$ " is $9 \mathrm{ft}$; and " $\mathrm{D}$ " is $12 \mathrm{ft}$ bgs for backhoe excavations. The actual depth intervals used for sampling were documented on Sample Collection Logs and are shown in Table A.2-1.

\section{A.2.1.2 Geoprobe ${ }^{\circledR}$ Soil Sampling}

A Geoprobe ${ }^{\circledR}$ was used to collect soil samples at 13 of the 19 sample locations within the Area 22 Sewage Lagoons site (Figure A.2-1). The Geoprobe ${ }^{\circledR}$ soil samples were collected using a Geoprobe Macrocore ${ }^{\circledR}$ sampler (2-in. outside diameter) with polyvinyl chloride (PVC) liners. In general, the samples were removed from the PVC liner at the planned sampling interval. At sample locations, 22SL001 through 22SL009, and 22SL016 and 22SL017, soil samples were collected from 1 to $2 \mathrm{ft}$ and 3 to $4 \mathrm{ft}$ bgs. At sample locations 22SL010 and 22SL011, within the southern most sewage lagoon, soil samples were only collected from the 2-ft interval because a caliche layer was encountered at approximately 2.5 to $3 \mathrm{ft}$ bgs. No sludge layer (a layer of organic rich material) was visually identified within the sewage lagoons.

\section{A.2.1.3 Trench/Test Pit Soil Sampling}

A backhoe was used to to collect samples at six sample locations (Figure A.2-1). At these sample locations, a trench/test pit was excavated and soil samples were collected either from the trench/test pit or from the backhoe bucket. At sample locations 22SL012 through 22SL015 (within in the middle and northernmost sewage lagoons) soil samples were collected with the backhoe from the 2-ft depth interval because a caliche layer was encountered at about 2.5 to $3 \mathrm{ft}$ bgs. Originally, samples at these locations were planned to be collected using a Geoprobe ${ }^{\circledR}$. A decision to use the backhoe at these locations was made because caliche was encountered using the Geoprobe ${ }^{\circledR}$ at sample locations 22SL010, 22SL011 (southernmost lagoon), and 22SL012 (middle lagoon). The backhoe was not able to penetrate through the caliche layer and sampling stopped at approximately $2 \mathrm{ft}$ bgs. In the sludge bed area, the depth that soil samples were collected ranged between 3 to $10.5 \mathrm{ft}$ bgs. The final depth that soil samples were collected was limited by the caliche layer. No sludge was identified in the sludge bed area or sewage lagoons. However, the old soil horizon in the sludge bed was sampled. The old soil horizon is located immediately below the asphalt debris and was identified by a root zone and some plant material. 


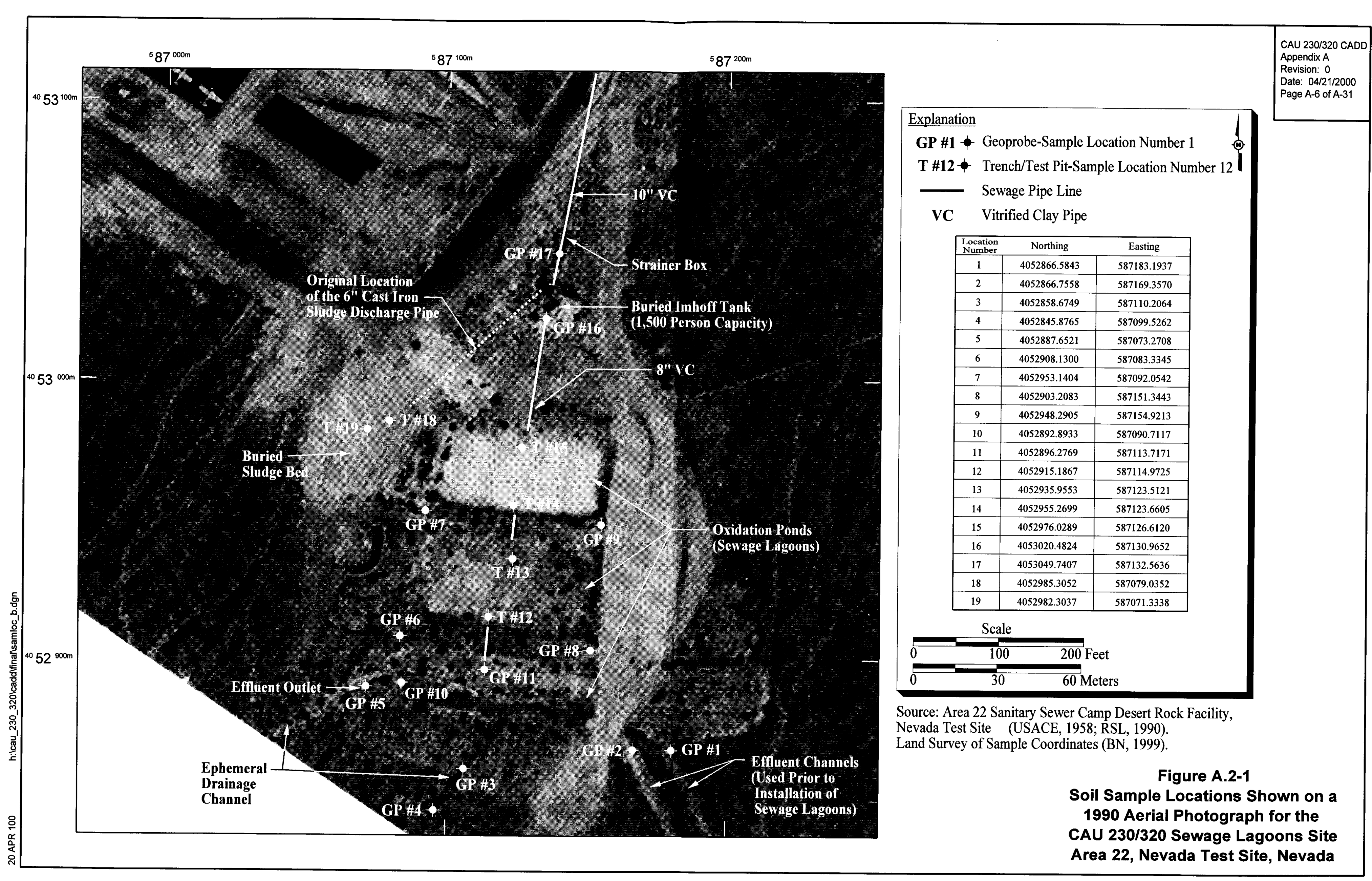


Table A.2-1

\section{Samples Collected and Submitted for Laboratory Analyses for the CAU 230/320 Area 22 Sewage Lagoons Corrective Action Investigation} (Page 1 of 3 )

\begin{tabular}{|c|c|c|c|c|c|}
\hline $\begin{array}{c}\text { Sample Location } \\
\text { and Number }\end{array}$ & $\begin{array}{c}\text { Depth } \\
\text { (feet below } \\
\text { ground surface) }\end{array}$ & $\begin{array}{l}\text { Sample } \\
\text { Matrix }\end{array}$ & $\begin{array}{l}\text { Sampling } \\
\text { Area }\end{array}$ & Sample Type & Parameters Analyzed \\
\hline 22SL001A & $1-2$ & Soil & Effluent Channel & Environmental Sample & SVOC \\
\hline 22SL001B & $3-4$ & Soil & Effluent Channel & Environmental Sample & SVOC \\
\hline 22SL002A & $0-1$ & Soil & Effluent Channel & Environmental Sample & SVOC \\
\hline 22SL002B & $3-4$ & Soil & Effluent Channel & Environmental Sample & SVOC \\
\hline 22SL003A & $1-2$ & Soil & Drainage Channel & Environmental Sample & SVOC \\
\hline 22SL003B & $3-4$ & Soil & Drainage Channel & Environmental Sample & SVOC \\
\hline 22SL004A & $1-2$ & Soil & Drainage Channel & Environmental Sample & SVOC \\
\hline 22SL004B & $3-4$ & Soil & Drainage Channel & Environmental Sample & SVOC \\
\hline 22SL005A & $1-2$ & Soil & Effluent Channel & Environmental Sample & SVOC \\
\hline 22SL005B & $3-4$ & Soil & Effluent Channel & Environmental Sample & SVOC \\
\hline 22SL006A & $1-2$ & Soil & Berm Soil & Environmental Sample & SVOC \\
\hline 22SL006B & $3-4$ & Soil & Berm Soil & Environmental Sample & SVOC \\
\hline 22SL007A & $1-2$ & Soil & Berm Soil & Environmental Sample & SVOC \\
\hline 22SL007B & $3-4$ & Soil & Berm Soil & Environmental Sample & SVOC \\
\hline 22SL008A & $1-2$ & Soil & Berm Soil & Environmental Sample & SVOC \\
\hline 22SL008B & $3-4$ & Soil & Berm Soil & Environmental Sample & SVOC \\
\hline 22SL008F & $3-4$ & Soil & Berm Soil & $\begin{array}{l}\text { Field Duplicate of } \\
\text { 22SL008B }\end{array}$ & SVOC \\
\hline 22SL009A & $1-2$ & Soil & Berm Soil & Environmental Sample & SVOC \\
\hline 22SL009B & $3-4$ & Soil & Berm Soil & Environmental Sample & SVOC \\
\hline 22SL010A & $1-2$ & Soil & Southern Lagoon - Outlet & $\begin{array}{l}\text { Environmental Sample } \\
\text { and MS/MSD }\end{array}$ & SVOC \\
\hline 22SL011A & $1-2$ & Soil & Southern Lagoon - Inlet & Environmental Sample & SVOC \\
\hline 22SL012A & $\sim 2$ & Soil & Middle Lagoon - Outlet & Environmental Sample & SVOC \\
\hline 22SL013A & $\sim 2$ & Soil & Middle Lagoon - Inlet & Environmental Sample & SVOC \\
\hline 22SL014A & $\sim 2$ & Soil & Northern Lagoon - Outlet & Environmental Sample & SVOC \\
\hline 22SL015A & $\sim 2.5$ & Soil & Northern Lagoon - Inlet & Environmental Sample & SVOC \\
\hline 22SL016A & $1-2$ & Soil & Imhoff Tank - Outlet & Environmental Sample & SVOC \\
\hline 22SL016B & $3-4$ & Soil & Imhoff Tank - Outlet & Environmental Sample & SVOC \\
\hline 22SL017A & $1-2$ & Soil & Imhoff Tank - Inlet & Environmental Sample & SVOC \\
\hline 22SL017B & $3-4$ & Soil & Imhoff Tank - Inlet & Environmental Sample & SVOC \\
\hline 22SL018A & $\sim 3$ & Soil & $\begin{array}{c}\text { Sludge Bed - Northeast } \\
\text { Corner }\end{array}$ & Environmental Sample & $\begin{array}{c}\text { VOC, SVOC, TPH-gasoline, } \\
\text { TPH-diesel }\end{array}$ \\
\hline 22SL018B & $\sim 6$ & Soil & $\begin{array}{c}\text { Sludge Bed - Northeast } \\
\text { Corner }\end{array}$ & Environmental Sample & $\begin{array}{c}\text { VOC, SVOC, TPH-gasoline, } \\
\text { TPH-diesel }\end{array}$ \\
\hline
\end{tabular}


Table A.2-1

\section{Samples Collected and Submitted for Laboratory Analyses for the CAU 230/320 Area 22 Sewage Lagoons Corrective Action Investigation} (Page 2 of 3 )

\begin{tabular}{|c|c|c|c|c|c|}
\hline $\begin{array}{l}\text { Sample Location } \\
\text { and Number }^{\mathrm{a}}\end{array}$ & $\begin{array}{c}\text { Depth } \\
\text { (feet below } \\
\text { ground surface) }\end{array}$ & $\begin{array}{l}\text { Sample } \\
\text { Matrix }\end{array}$ & $\begin{array}{l}\text { Sampling } \\
\text { Area }\end{array}$ & Sample Type & Parameters Analyzed \\
\hline 22SL018C & $\sim 9$ & Soil & $\begin{array}{c}\text { Sludge Bed - Northeast } \\
\text { Corner }\end{array}$ & Environmental Sample & $\begin{array}{c}\text { VOC, SVOC, TPH-gasoline, } \\
\text { TPH-diesel }\end{array}$ \\
\hline 22SL018D & $\sim 10.5$ & Soil & $\begin{array}{c}\text { Sludge Bed - Northeast } \\
\text { Corner }\end{array}$ & Environmental Sample & $\begin{array}{l}\text { VOC, SVOC, TPH-gasoline, } \\
\text { TPH-diesel, TCLP VOC, } \\
\text { TCLP SVOC, TCLP RCRA } \\
\text { metals, TCLP pesticides, } \\
\text { Gamma Spectrometry }\end{array}$ \\
\hline 22SL018F & $\sim 10.5$ & Soil & $\begin{array}{c}\text { Sludge Bed - Northeast } \\
\text { Corner }\end{array}$ & $\begin{array}{l}\text { Field Duplicate of } \\
\text { 22SL018D }\end{array}$ & $\begin{array}{l}\text { VOC, SVOC, TPH-gasoline, } \\
\text { TPH-diesel, TCLP VOC, } \\
\text { TCLP SVOC, TCLP RCRA } \\
\text { metals, TCLP pesticides, } \\
\text { Gamma Spectrometry }\end{array}$ \\
\hline 22SL019A & $\sim 3$ & Soil & $\begin{array}{c}\text { Sludge Bed - Southwest } \\
\text { Corner }\end{array}$ & Environmental Sample & $\begin{array}{c}\text { VOC, SVOC, TPH-gasoline, } \\
\text { TPH-diesel }\end{array}$ \\
\hline 22SL019B & $\sim 6$ & Soil & $\begin{array}{c}\text { Sludge Bed - Southwest } \\
\text { Corner }\end{array}$ & $\begin{array}{l}\text { Environmental Sample } \\
\text { and MS/MSD }\end{array}$ & $\begin{array}{c}\text { VOC, SVOC, TPH-gasoline, } \\
\text { TPH-diesel }\end{array}$ \\
\hline 22SL019C & $\sim 8$ & Soil & $\begin{array}{c}\text { Sludge Bed - Southwest } \\
\text { Corner }\end{array}$ & Environmental Sample & $\begin{array}{c}\text { VOC, SVOC, TPH-gasoline, } \\
\text { TPH-diesel }\end{array}$ \\
\hline 22SL019D & $\sim 8.5$ & Soil & $\begin{array}{c}\text { Sludge Bed - Southwest } \\
\text { Corner }\end{array}$ & Environmental Sample & $\begin{array}{c}\text { VOC, SVOC, TPH-gasoline, } \\
\text { TPH-diesel }\end{array}$ \\
\hline 22SL020 & NA & Water & NA & $\begin{array}{l}\text { Equipment Rinsate } \\
\text { Blank }\end{array}$ & SVOC \\
\hline 22SL021 & NA & Water & NA & Source Blank & SVOC \\
\hline 22SL022 & NA & Water & NA & Field Blank & SVOC \\
\hline 22SL023 & NA & Water & NA & $\begin{array}{l}\text { Equipment Rinsate } \\
\text { Blank }\end{array}$ & SVOC \\
\hline 22SL024 & NA & Water & NA & Trip Blank & VOC \\
\hline 22SL025 & NA & Water & NA & Trip Blank & VOC \\
\hline 22SL026 & NA & Water & NA & Trip Blank & VOC \\
\hline 22SL027 & NA & Water & NA & $\begin{array}{l}\text { Equipment Rinsate } \\
\text { Blank }\end{array}$ & $\begin{array}{c}\text { VOC, SVOC, TPH-gasoline, } \\
\text { TPH-diesel, Total RCRA } \\
\text { metals, Total pesticides, } \\
\text { Gamma Spectrometry }\end{array}$ \\
\hline 22SL028 & NA & Water & NA & Trip Blank & VOC \\
\hline
\end{tabular}


Table A.2-1

\section{Samples Collected and Submitted for Laboratory Analyses for the CAU 230/320 Area 22 Sewage Lagoons Corrective Action Investigation} (Page 3 of 3 )

\begin{tabular}{|c|c|c|c|c|c|}
\hline $\begin{array}{c}\text { Sample Location } \\
\text { and Number }\end{array}$ & $\begin{array}{c}\text { Depth } \\
\text { (feet below } \\
\text { ground surface) }\end{array}$ & $\begin{array}{c}\text { Sample } \\
\text { Matrix }\end{array}$ & $\begin{array}{c}\text { Sampling } \\
\text { Area }\end{array}$ & Sample Type & Parameters Analyzed \\
\hline 22 SL029 & NA & Water & NA & Field Blank & $\begin{array}{c}\text { VOC, SVOC, TPH-gasoline, } \\
\text { TPH-diesel, Total RCRA } \\
\text { metals, Total pesticides, } \\
\text { Gamma Spectrometry }\end{array}$ \\
\hline 22SL030 & NA & Water & NA & Trip Blank & VOC \\
\hline
\end{tabular}

${ }^{a}$ The correlation between sample locations and sample numbers is explained in Section A.2.1.1. MS/MSD = Matrix spike and matrix spike duplicate $\mathrm{NA}=$ Not applicable VOC $=$ Volatile organic compounds $\mathrm{TPH}=$ Total petroleum hydrocarbons RCRA $=$ Resource Conservation and Recovery Act SVOC $=$ Semivolatile organic compounds TCLP $=$ Toxicity Characteristic Leaching Procedure $\sim$ = approximately

\section{A.2.2 Field Screening}

Field-screening levels (FSLs) were used to guide soil sample collection and the selection of samples for laboratory analysis. The FSL for TPH field-screening results was established at $100 \mathrm{mg} / \mathrm{kg}$ to coincide with the NDEP action level for TPH (NAC, 1999). The FSL for VOCs was 20 parts per million (ppm) or 2.5 times background, whichever was higher. The field-screening level for alpha/beta radiological field survey was established as the mean of 20 surficial-background activity level locations plus two times the standard deviation of the mean surficial-background activity level (DOE/NV, 1999). Field screening and surveys were performed as specified in the CAIP (DOE/NV, 1999). The screening and survey methods included the following:

- Radiological survey for alpha and beta emitters using an Electra instrument

- Headspace screening for VOCs using a photoionization detector

- TPH screening using a colorimetric field testing kit manufactured by Hanby Environmental Laboratory Procedures, Inc.

In general, when a sample's field-screening results were below the established FSLs, the sample was sent to the laboratory for SVOC analysis only. When a sample's field-screening results were above 
the established FSLs, the sample was sent to the laboratory for VOC, SVOC, and TPH as gasolineand diesel-range organics analyses, as necessary. Field-screening results were below established FSLs for samples 22SL001 through 22SL017 (outside the sludge bed area) and they were analyzed for SVOCs only. Only the samples collected from within the sludge bed area indicated field-screening results greater than the established FSLs. Hanby field-screening results at sample locations 22SL018 and 22SL019 (within the sludge bed area) indicated the presence of TPH above the established FSLs. Hanby results ranged from approximate $200 \mathrm{mg} / \mathrm{kg}$ to greater than $1,000 \mathrm{mg} / \mathrm{kg}$. All the samples collected from the sludge bed area were sent to the laboratory and analyzed for VOCs, SVOCs, and TPH as gasoline- and diesel-range organics. Samples in the sludge bed area were also collected for waste management purposes. See Table A.2-1 for a complete list of samples collected and submitted for laboratory analyses.

\section{A.2.3 Sludge Bed Description and Cross-Section}

Asphalt debris/soil with four yellow and black-stripped safety poles and a couple strands of barbed wire were uncovered during excavation of the sludge bed trenches/test pits (22SL018 and 22S1019). This asphalt debris/soil is the most-likely source for the TPH as diesel-range organics (the profile was most similar to motor oil) detected in the samples collected from this location. See Figure A.2-2 for a generalized cross-section of the sludge bed. Based on review of Area 22 aerial photographs that show the sewage lagoons site, it appears the debris was buried in the sludge bed between September 1980 and March 1982. The soil horizon below the debris between 8 and $9 \mathrm{ft}$ bgs contained bits of roots and plant material and is probably the historic surface of the sludge bed (prior to being covered with the debris). However, no distinctive organic sludge layer was apparent. Caliche was found at 8.5 and $10.5 \mathrm{ft}$ bgs. All the samples were collected as planned in the CAIP (DOE/NV, 1999) except for locations where caliche was encountered and then the final sampling depth was reduced to the maximum attainable depth.

\section{A.2.4 Soil Sampling}

The VOC, TPH as gasoline-range organics, headspace, and Hanby field-screening soil samples were collected first and immediately placed into appropriate containers. The VOC and TPH as gasoline-range orgaincs containers were immediately placed on ice. Field screening was conducted. If field-screening results were below FSLs, the sample collected for VOCs was relabeled and 


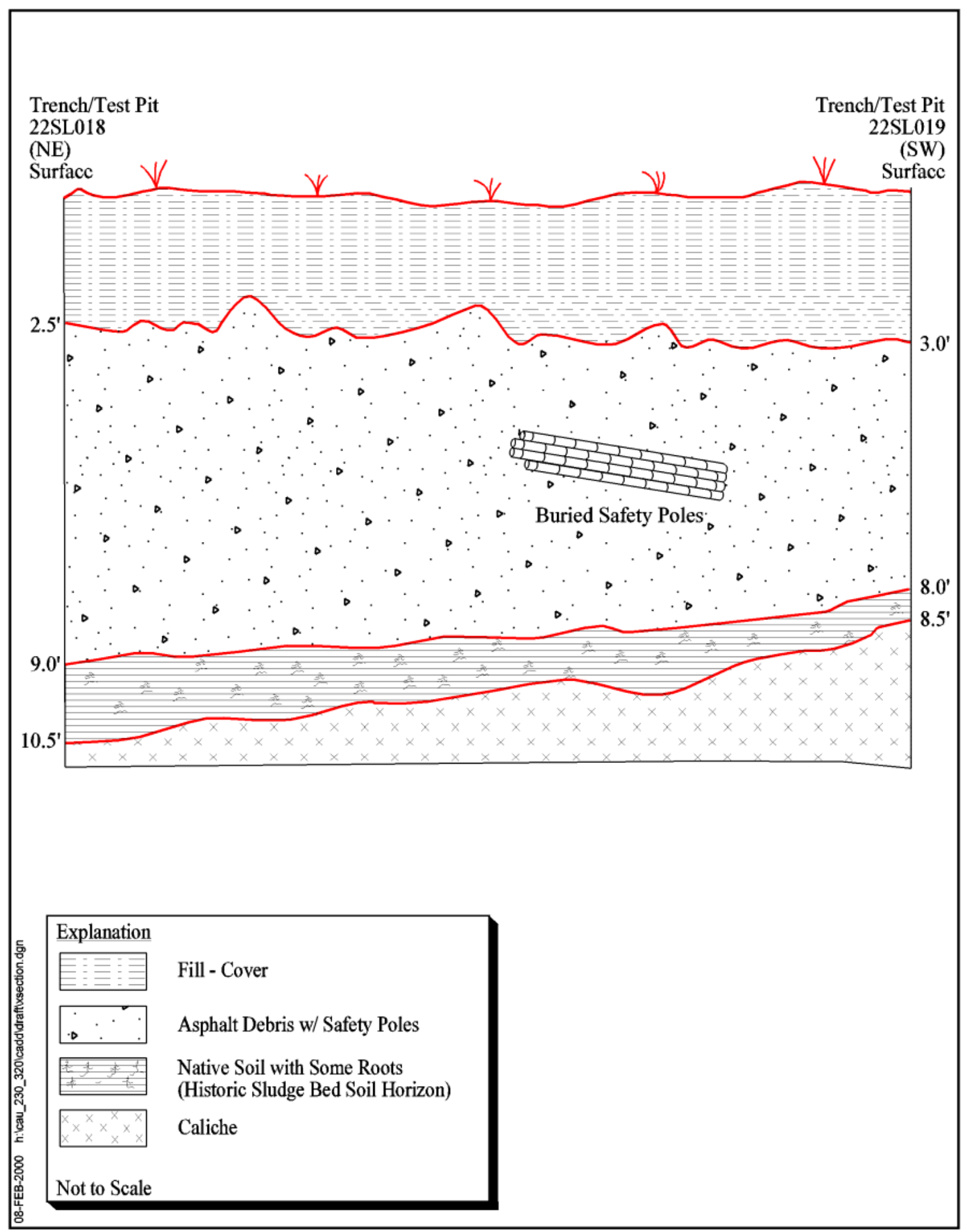

Figure A.2-2

Generalized Cross-Section of the Sludge Bed, CAU 230/320 Sewage Lagoons Site, Area 22, Nevada Test Site, Nevada 
submitted to the laboratory for SVOC analyses only and the TPH as gasoline-range organics sample was returned to the sample location from which it was collected. However, if field-screening results were above established FSLs, the VOC and TPH as gasoline-range organics samples were submitted to the laboratory for the specified analyses and additional soil was collected from the same soil horizon for TPH as diesel-range organics and SVOC analyses. The SVOC and TPH as diesel-range organics samples were homogenized in a steel bowl and then spooned into an appropriate sample container. Additional samples were collected from the sludge bed area for waste management purposes. The samples collected for waste management purposes were submitted to be analyzed for TCLP VOC, TCLP SVOC, TCLP RCRA metals, TCLP pesticides, and gamma spectrometry. The most volatile samples were collected first followed by samples with decreasing volatility. The less volatile samples were homogenized in a steel bowl with a steel spoon then placed into the sample container as appropriate.

\section{A.2.5 Number of Samples Collected and Submitted for Analyses}

Thirty-eight soil samples were collected and submitted for laboratory analyses from 19 sample locations (Table A.2-1 and Figure A.2-1). Any excess soil from sampling was returned to the associated sample location.

\section{A.2.6 Geology}

The alluvial fan soil at the Area 22 Sewage Lagoons site consists of poorly-sorted silt, sand, abundant gravel, and some cobbles. Caliche was encountered, within the sewage lagoons at approximately 2.5 and $3 \mathrm{ft}$ bgs, and in the sludge bed area at approximately 8.5 and $10.5 \mathrm{ft}$ bgs. The thickness of the caliche is unknown. The caliche was hard and could not be penetrated with the Geoprobe ${ }^{\circledR}$ or backhoe.

\section{A.2.7 Hydrology}

Groundwater at the Area 22 Sewage Lagoons site is not expected to be impacted by COPC migration due to the depth to groundwater. At Mercury Valley, the depth to groundwater ranges from 800 to 1,100 ft bgs (Winograd and Thordarson, 1975; Robie et al., 1995). There are no perennial surface water sources at the Area 22 Sewage Lagoons. Localized heavy precipitation events may cause 
flooding at the CAU 230/320 site; however, the COC is not expected to be mobilized because analytical results indicate that contamination in the sludge bed area is primarily between 3 to $9 \mathrm{ft}$ bgs. 


\section{A.3.0 Investigation Results}

The samples collected for the CAU 230/320 site were submitted to Paragon Analytics, Inc. for analyses. The analytical parameters and laboratory analytical methods conducted for the CAU 230/320 investigation are shown in Table A.3-1. The analytical results of soil samples collected from the CAU 230/320 site have been compiled and evaluated to determine the presence and/or extent of contamination. The analytical results that are above the minimum reporting limits are summarized in the following subsections. A list of the samples collected and analyzed for the investigation are shown in Table A.2-1. The analytical parameters and laboratory analytical methods conducted for the CAU 230/320 investigation are shown in Table A.3-1.

Table A.3-1

Laboratory Analytical Methods Conducted for Samples Collected During the CAU 230/320 Area 22 Sewage Lagoons Corrective Action Investigation

\begin{tabular}{|c|c|}
\hline Analytical Parameter & Analytical Method \\
\hline Total volatile organic compounds & EPA $8260 B^{a}$ \\
\hline Total semivolatile organic compounds & EPA $8270 C^{a}$ \\
\hline Total petroleum hydrocarbons - as gasoline and as diesel-range organics & EPA 8015B (modified) ${ }^{a}$ \\
\hline Total RCRA metals (QC samples only) & EPA $6010 \mathrm{~B} / 7470 \mathrm{~A}^{\mathrm{a}}$ \\
\hline Total pesticides (QC samples only) & EPA $8081 A^{a}$ \\
\hline TCLP volatile organic compounds & EPA $1311 / 8260 B^{a}$ \\
\hline TCLP semivolatile organic compounds & EPA $1311 / 8270 C^{a}$ \\
\hline TCLP RCRA metals & EPA $1311 / 6010 B / 7470 A^{a}$ \\
\hline TCLP pesticides & EPA $1311 / 8081 A^{a}$ \\
\hline Gamma Spectrometry & $\begin{array}{l}\text { HASL } 300^{\mathrm{b}} \\
\text { EPA } 901.1^{\mathrm{c}}\end{array}$ \\
\hline
\end{tabular}

a EPA Test Methods for Evaluating Solid Waste, 3rd Edition, Parts 1-4, SW-846 (EPA, 1996)

b Environmental Measurements Laboratory Procedures Manual (DOE, 1997) or equivalent method

${ }^{c}$ Prescribed Procedures for Measurements of Radioactivity in Drinking Water (EPA, 1980) or equivalent method 
The analytical parameters were selected through the application of site process knowledge according to the EPA's Guidance for the Data Quality Objectives Process (EPA, 1994c). Preliminary action levels for off-site laboratory analytical methods were determined during the DQO process and are documented in the CAIP (DOE/NV, 1999). Sampling activities were conducted to assess the conceptual site model assumptions developed during the DQO process and outlined in CAIP (DOE/NV, 1999).

\section{A.3.1 Total Volatile Organic Compound Analytical Results}

The total VOC analytical results detected above minimum reporting limits established in the CAIP (DOE/NV, 1999) are presented in Table A.3-2. None of these results exceeded the PAL (DOE/NV, 1999).

Acetone is common laboratory-introduced contaminant and its presence in these soil samples could be attributed to this factor (see Section A.4.7.1). The concentrations of this contaminant is well below established PALs (DOE/NV, 1999).

Table A.3-2

Soil Sample Results for Total Volatile Organic Compounds Detected Above Minimum Reporting Limits, CAU 230/320 Area 22 Sewage Lagoons Site, Nevada Test Site

\begin{tabular}{|c|c|c|}
\hline \multirow{3}{*}{ Sample Location and Number ${ }^{b}$} & \multirow{2}{*}{$\begin{array}{l}\text { Sample Depth } \\
\text { (ft bgs) }\end{array}$} & $\begin{array}{l}\text { Contaminants of Potential Concern } \\
\text { in Micrograms per Kilogram }(\mu \mathrm{g} / \mathrm{kg})\end{array}$ \\
\hline & & Acetone \\
\hline & Residential/Industrial PRGa & $1,400,000 / 6,100,000$ \\
\hline 22SL018C & $\sim 9$ & 28 \\
\hline 22SL019A & $\sim 3$ & 28 \\
\hline 22SL019D & $\sim 8.5$ & $23(\mathrm{~J})^{\mathbf{c}, \mathbf{d}, \mathbf{e}}$ \\
\hline
\end{tabular}

\footnotetext{
${ }^{a}$ Environmental Protection Agency Region 9, Industrial Preliminary Remediation Goals (PRG) (EPA, 1998)

${ }^{\mathrm{b}}$ The correlation between sample locations and sample numbers is explained in Section A.2.1.1.

"Matrix effect may exist

dInternal standard area count exceeded QC limits

eSurrogate recovery exceeded the upper limits

$\mathrm{J}=$ Estimated value

$\sim$ = Approximately
} 


\section{A.3.2 Total Semivolatile Organic Compound Analytical Results}

None of the SVOC analytical results are above the minimum reporting limits; therefore, all of the results are below the established PALs (DOE/NV, 1999).

\section{A.3.3 Total Petroleum Hydrocarbon Results}

Total petroleum hydrocarbons were detected in the diesel range above the minimum reporting limit and above the NDEP regulatory action level of $100 \mathrm{mg} / \mathrm{kg}$ (NAC, 1999) from sample locations 22SL018 and 22SL019, within the sludge bed area, as shown in Table A.3-3.

Table A.3-3

Soil Sample Results for Total Petroleum Hydrocarbons Detected Above Minimum Reporting Limits, CAU 230/320 Area 22 Sewage Lagoons Site, Nevada Test Site

\begin{tabular}{|c|c|c|}
\hline \multirow{2}{*}{$\begin{array}{c}\text { Sample Location and } \\
\text { Number }\end{array}$} & $\begin{array}{c}\text { Sample Depth } \\
(\mathrm{ft} \text { bgs })\end{array}$ & $\begin{array}{c}\text { Contaminants of Potential } \\
\text { Concern } \\
(\mathrm{mg} / \mathrm{kg})\end{array}$ \\
\cline { 2 - 3 } & Preliminary Action Level $^{\mathrm{a}}$ & Diesel \\
\hline \hline 22SL018B & $\sim 6$ & $\mathbf{1 0 0}$ \\
\hline 22SL018C & $\sim 9$ & $\mathbf{5 8 0}$ \\
\hline 22SL019A & $\sim 3$ & $\mathbf{1 5 0}$ \\
\hline 22SL019B & $\sim 6$ & $\mathbf{3 8 0}$ \\
\hline 22SL019C & $\sim 8$ & $36(\mathrm{~J})^{\mathrm{c}}$ \\
\hline
\end{tabular}

${ }^{a}$ Nevada Administrative Code 445A.2272 for total petroleum hydrocarbons (NAC, 1999)

${ }^{\mathrm{b}}$ The correlation between sample locations and sample numbers is explained in Section A.2.1.1.

'Duplicate precision analyses were outside control limits

$\mathrm{J}=$ Estimated value

Bolded values indicate analytical results that exceed the $100 \mathrm{mg} / \mathrm{kg}$ NDEP established action level.

$\sim$ Approximately

\section{A.3.4 TCLP VOC Results}

None of the TCLP VOC results are above the minimum reporting limit (DOE/NV, 1999).

\section{A.3.5 TCLP SVOC Results}

None of the TCLP SVOC results were above the minimum reporting limits (DOE/NV, 1999). 


\section{A.3.6 TCLP RCRA Metals Results}

None of the results of the TCLP RCRA metals analyses were above the minimum reporting limits (DOE/NV, 1999).

\section{A.3.7 TCLP Pesticide Results}

None of the results of the TCLP pesticide analyses were detected above the minimum reporting limits (DOE/NV, 1999).

\section{A.3.8 Gamma Spectrometry Results}

The gamma spectrometry results are within background levels as shown in Table A.3-4 (DOE/NV, 1999).

Table A.3-4

Summary of Gamma Spectrometry Results Detected Above Minimum Reporting Limits, CAU 230/320 Area 22 Sewage Lagoons, Nevada Test Site

\begin{tabular}{||c|c|c|c|c|c||}
\hline \multirow{2}{*}{$\begin{array}{c}\text { Sample } \\
\text { Location and } \\
\text { Number }\end{array}$} & \multirow{2}{*}{$\begin{array}{c}\text { Sample Depth } \\
\text { (ft bgs) }\end{array}$} & \multicolumn{4}{|c||}{ Contaminants of Potential Concern (pCi/g) } \\
\cline { 2 - 6 } & Background & Bismuth-214 & Potassium-40 & Lead-212 & Lead-214 \\
\cline { 2 - 6 } & $\sim \mathbf{0 . 1 - 3 . 4 7 ^ { \mathrm { a } }}$ & $\mathbf{1 1 - 9 6 ^ { \mathrm { a } }}$ & $\mathbf{0 . 8 9 - 2 . 9 ^ { \mathrm { a } }}$ & $\mathbf{0 . 5}-\mathbf{2 . 9 ^ { \mathrm { b } }}$ \\
\hline \hline $22 \mathrm{SL018D}$ & $\sim 10.5$ & $0.59 \pm 0.32$ & $9.5 \pm 3.0$ & $0.47 \pm 0.18$ & $0.50 \pm 0.21$ \\
\hline $22 \mathrm{SL018F}^{\star}$ & $\sim 10.5$ & -- & $8.9 \pm 3.0$ & $0.46 \pm 0.18$ & $0.72 \pm 0.25$ \\
\hline
\end{tabular}

${ }^{\mathrm{a}}$ Environmental Monitoring Report for the Proposed Ward Valley California Low Level Radioactive Waste Facility (U.S. Ecology and Atlan-Tech, 1992)

${ }^{b}$ Soil concentrations are calculated values derived from the uranium-238, thorium-232, and plutonium-239/240 concentrations reported in "Off-site Radiation Exposure Review Project Phase II Soil Program" (McArthur and Miller, 1989)

${ }^{\mathrm{c}}$ The correlation between sample locations and sample numbers is explained in Section A.2.1.1.

*Sample is a field duplicate for sample 22SL018D

-- = Not detected above minimum reporting limit

$\sim$ Approximately 


\section{A.4.0 Quality Assurance}

The results of the QA/QC activities for the CAU 230/320 corrective action investigation sampling events are summarized in the following text. Detailed information regarding the QA program is contained in the Industrial Sites QAPP (DOE/NV, 1996).

Quality control results are typically judged in terms of precision, accuracy, representativeness, completeness, and comparability and are described in the following sections.

\section{A.4.1 Precision}

Precision is a quantitative measure of the variability of a group of measurements from their average value. Precision is assessed for inorganic analysis by collecting and analyzing duplicate field samples and comparing the results with the original sample. Precision is also assessed by creating, preparing, analyzing, and comparing laboratory duplicates from one or more field samples in inorganic analyses and matrix spike and matrix spike duplicate (MS/MSD) samples for organic analyses. Precision is reported as relative percent difference (RPD) which is calculated as the difference between the measured concentrations of duplicate samples, divided by the average of the two concentrations, and multiplied by 100. Any deviation from these requirements has been documented and explained and the related data qualified accordingly. The qualification process is described in Section A.4.7.1.

\section{A.4.2 Accuracy}

Analytical accuracy is defined as the nearness of a measurement to the true or accepted reference value. It is the composite of the random and systematic components of the measurement system and measures bias in the measurement system. The random component of accuracy is measured and documented through the analyses of spiked samples. Sampling accuracy is assessed by evaluating the results of spiked samples and laboratory control samples. Accuracy measurements are calculated as percent recovery by dividing the measured sample concentration by the true concentration and multiplying the quotient by 100 .

Field accuracy is assessed by confirming that the documents of record track the sample from its origin, through transfer of custody, to disposal. The goal of field accuracy is for all samples to be 
collected from the correct locations at the correct time, placed in a correctly labeled container with the correct preservative, and sealed with custody tape to prevent tampering. All samples in this sampling event were properly collected and forwarded to the laboratories as described above.

\section{A.4.3 Representativeness}

Representativeness expresses the degree to which sample data accurately and precisely represent a characteristic of a population, parameter variations at a sampling point, or an environmental condition (EPA, 1987). Sample representativeness was achieved through the implementation of a sampling program designed to ensure proper sampling locations, number of samples, and the use of validated analytical methods. Representativeness was assessed through analysis of duplicate samples. Representativeness of the samples taken in this sampling event was assured by collecting the specified number of samples (DOE/NV, 1999) and by analyzing them by the approved analytical methods shown in Table A.3-1.

\section{A.4.4 Completeness}

Completeness is defined as a percentage of measurements made that are judged to be valid. A sampling and analytical requirement of 80 percent completeness was established and achieved for this project with a portion of the acrolein results for quality control water samples were rejected during data validation. The acrolein results were rejected due to the instrument response not meeting QC criteria (DOE/NV, 1996). The rejected results represent an acceptable data gap because acrolein was not expected in these samples and was not detected in the associated environmental samples.

The specified sampling locations were utilized as planned. All samples were collected as specified in the CAIP (DOE/NV, 1999), and all sample containers reached the laboratory intact and properly preserved. Sample temperatures were maintained during shipment to the laboratory, and sample chain of custody was maintained during sample storage and/or shipment.

\section{A.4.5 Comparability}

Comparability is a qualitative parameter expressing the confidence with which one data set can be compared to another (EPA, 1987). To ensure comparability, the field and sampling activities at the Area 22 Sewage Lagoons were performed and documented in accordance with approved procedures, 
and all samples were collected in accordance with the CAIP (DOE/NV, 1999). Approved standardized methods and procedures were also used to analyze and report the data (e.g., Contract Laboratory Program [CLP] and/or CLP-like data packages). This approach ensures that the data from this project can be compared to other data sets. Based on the minimum comparability requirements specified in the Industrial Sites QAPP (DOE/NV, 1996), all requirements were met.

Field (i.e., sample-handling) documentation, laboratory nonconformance reports, and the precision and accuracy of quality-control sample results were evaluated for their effect on the results of the associated environmental soil samples. The environmental sample results were then qualified according to processes outlined in the following sections. Documentation of the data qualifications resulting from these reviews is retained in project files as both hard copy and electronic media.

\section{A.4.6 Tier I and Tier II Data Evaluations}

All laboratory data from samples collected at the Area 22 Sewage Lagoons have been evaluated for data quality according to the EPA Functional Guidelines (EPA, 1994a and 1994b). These guidelines are implemented in a tiered process and are presented in the following text. No data rejected during the data evaluation process were used to draw the conclusions presented in the CADD. Only valid data, whether estimated (i.e., J-qualified) or not, were used.

The changes resulting from the data evaluation process were documented in project files and were summarized in memoranda for each sample delivery group (SDG). These memoranda are maintained with the SDGs in the project files.

\section{A.4.6.1 Tier I Evaluation}

Tier I evaluation for both chemical and radiological analysis examines (but is not limited to):

- Sample count/type consistent with chain of custody

- Analysis count/type consistent with chain of custody

- Correct sample matrix

- Significant problems stated in cover letter or case narrative

- Completeness of certificates of analysis

- Completeness of CLP or CLP-like packages

- Completeness of signatures, dates, and times on chain of custody

- Condition-upon-receipt variance form included 
- Requested analyses performed on all samples

- Date received/analyzed given for each sample

- Correct concentration units indicated

- Electronic data transfer supplied

- Results reported for field and laboratory QC samples

- Whether or not the deliverable met the overall objectives of the project

\section{A.4.6.2 Tier II Evaluation}

Tier II evaluation for chemical and radiological analysis examines (but is not limited to):

\section{Chemical:}

- Correct detection limits achieved

- Sample date, preparation date, and analysis date for each sample

- Holding time criteria met

- QC batch association for each sample

- Cooler temperature upon receipt

- Sample $\mathrm{pH}$ for aqueous samples, as required

- Detection limits properly adjusted for dilution, as required

- Blank contamination evaluated and applied to sample results/qualifiers

- $\quad$ MS/MSD percent recoveries (\%R) and RPDs evaluated and applied to laboratory results/qualifiers

- Field duplicate RPDs evaluated using professional judgement and applied to laboratory results/qualifiers

- Laboratory duplicate RPDs evaluated and applied to laboratory results/qualifiers

- $\quad$ Surrogate $\% \mathrm{R}$ evaluated and applied to laboratory results/qualifiers

- Laboratory control sample $\% \mathrm{R}$ evaluated and applied to laboratory results/qualifiers

- Initial and continuing calibration evaluated and applied to laboratory results/qualifiers

- Internal standard evaluated and applied to laboratory results/qualifiers 
- Mass spectrometer tuning criteria

- Organic compound quantitation

- Inductively coupled plasma (ICP) interface check sample evaluation

- ICP serial dilution effects

- Recalculation of 10 percent of laboratory results from raw data

\section{Radioanalytical:}

- Correct detection limits achieved

- Blank contamination evaluated and applied to sample results/qualifiers

- Certificate of Analysis consistent with data package documentation

- Quality control sample results (duplicates, laboratory control samples, laboratory blanks) evaluated and applied to laboratory result qualifiers

- Detector system calibrated to National Institute for Standards and Technology (NIST) traceable sources

- Calibration sources preparation was documented, demonstrating proper preparation and appropriateness for sample matrix, emission energies, and concentrations

- Detector system response to daily, weekly, and monthly background and calibration checks, which may include peak energy, peak centroid, peak full-width half-maximum, and peak efficiency, depending on the detection system

- Tracers NIST-traceable, appropriate for the analysis performed, and recoveries that met QC requirements

- Documentation of all QC sample preparation complete and properly performed

- QC sample results (e.g., calibration source concentration, \%R, and RPD) verified

- Spectra lines, emissions, particle energies, peak areas, and background peak areas support the identified radionuclide and its concentration

- Recalculation of 10 percent of laboratory results from raw data 


\section{A.4.6.3 Tier III}

The Tier III review looks at all the items evaluated in the Tier II evaluation, but for only a limited number of samples (typically 5 percent). It serves as a check on the Tier II process. The Tier III review includes the additional evaluations:

\section{Chemical:}

- Recalculation of laboratory results from raw data for all samples submitted for Tier III.

\section{Radioanalytical:}

- Radionuclides and their concentration appropriate considering their decay schemes, half-lives, and process knowledge and history of the facility and site.

- Each identified line in spectra verified against emission libraries and calibration results

- Independent identification of spectra lines, area under the peaks, and quantification of radionuclide concentration in a random number of sample results

- Recalculation of laboratory results from raw data for all samples submitted for Tier III

A Tier III review of at least five percent of the sample analytical data was performed by Laboratory Data Consultants, Carlsbad, CA. The result of the Tier III review did not cause any changes to the data.

\section{A.4.7 Quality Control Samples}

There were five trip blanks, two field blanks, one source blank, three equipment rinsate blanks, two MS/MSD, and two field duplicates collected and submitted for laboratory analysis as shown in Table A.2-1. The quality control samples and duplicates were assigned individual sample numbers and sent to the laboratory "blind." Additional samples were selected by the laboratory to be analyzed as laboratory duplicates. The field blanks were taken by placing distilled water into appropriate sample bottles and preserving them according to the requirements specified in the Industrial Sites QAPP (DOE/NV, 1996). The equipment rinsate blanks were obtained by collecting the final rinse solution (i.e., deionized water), which was poured over the decontaminated sampling equipment into the appropriate sample bottles and preserved as applicable. A source blank was also collected for the Geoprobe MacroCore ${ }^{\circledR}$ PVC liners by pouring water directly through the liners into sample containers 
and preserving them as appropriate. The trip blanks were received sealed and preserved from the laboratory and were placed in each cooler containing VOC samples. The results of the QC samples are discussed in the following sections.

\section{A.4.7.1 Field Quality Control Samples}

Review of the field-blank analytical data for the CAU 230/320 soil sampling indicates that cross-contamination from field methods did not occur during sample collection. Field, equipment rinsate, and source blanks were analyzed for the parameters listed in Table A.3-1 and trip blanks were analyzed for VOCs only. None of the results for these field blanks exceeded the minimum laboratory reporting limits (DOE/NV, 1999). Contaminants detected could be attributed to laboratoryintroduced contamination.

During the sampling event, two field duplicate soil samples were sent as blind samples to the laboratory to be analyzed for the investigation parameters listed in Table A.3-1. For these samples, the duplicate results precision (i.e., RPDs between the environmental sample results and their corresponding field duplicate sample results) were evaluated to the guidelines set forth in EPA Functional Guidelines (EPA, 1994a and 1994b). The EPA Functional Guidelines state that there are no required review criteria for field duplicate analyses comparability, but allow the data reviewer to exercise professional judgement. The RPD for arsenic concentrations between the environmental sample results and their corresponding field duplicate sample results exceeded the 20 percent criteria stated in the Industrial Sites QAPP (DOE/NV, 1996).

Two field samples were selected for use as MS/MSD samples. The percent recoveries of these samples (a measure of accuracy) and the relative percent differences in these sample results (a measure of precision) were compared to EPA Functional Guideline criteria (EPA, 1994a and 1994b). The results were used to qualify associated environmental sample results accordingly.

The EPA Functional Guidelines for review of organic data state that no data qualification action is taken on the basis of MS/MSD results alone. The data reviewer exercises professional judgement in considering these results in conjunction with the results of laboratory control samples (LCSs) and other QC criteria in applying qualifications to the data. 
The inorganic data review in EPA Functional Guidelines allows professional judgement to be applied in evaluating the results of matrix spikes. Generally, if the spike recovery is greater than the upper acceptance limit $(>125 \%)$, nondetect results are acceptable for use. If spike recovery is greater than the upper acceptance limit (>125\%) or less than the lower acceptance limit (<75\%), positive results are qualified as estimated (J). If spike recovery is within the range of 30-74\%, nondetect results are qualified as estimated (UJ). If spike recovery is $<30 \%$, nondetect results are qualified as unusable (R).

\section{A.4.7.2 Laboratory Quality Control Samples}

Analysis of method blanks, surrogate spikes, and laboratory control samples for organic analyses and preparation blanks, initial and continuing calibration blanks, and laboratory control samples for total RCRA metals and TCLP RCRA metals were performed for each SDG by Paragon Analytics, Inc. laboratory. The results of these analyses were used to qualify associated environmental sample results according to EPA Functional Guidelines (EPA, 1994a and 1994b).

The EPA Functional Guidelines (EPA, 1994a and 1994b) state that no qualification action is taken if a compound is found in an associated blank, but not in the sample or if a compound is found in the sample, but not in an associated blank. The action taken when a compound is detected in both the sample and the associated blank varies depending upon the analyte involved and is described in the "The 5X/10X Rule."

For VOCs, SVOCs, pesticides, and TPH diesel and gasoline if an analyte was detected in the sample and was also detected in an associated blank the result is qualified as undetected (U) if the sample concentration is less than 5 times $(5 \mathrm{X})$ the blank concentration.

For the common laboratory contaminants (e.g., methylene chloride, acetone, 2-butanone [methylethyl ketone or MEK], and phthalate esters [especially bis(2-ethylhexyl)phthalate]), the factor is raised to 10 times (10X) the blank concentration. The sample result is elevated to the quantitation limit if it is less than the quantitation limit or remains unaltered if the sample result is greater than or equal to the quantitation limit. 
For inorganic sample results greater than the instrument detection limit, but less than five times $(5 \mathrm{X})$ the amount found in an associated initial and continuing blank, are qualified as undetected (U). There are no metallic common laboratory contaminants, so there is no " $10 \mathrm{X}$ Rule" for metals, and the sample result is never altered. When applying the $5 \mathrm{X}$ criteria to soil sample data or calibration blank data, the raw data results are used to evaluate and qualify the reported results on the Certificate of Analysis. Preparation blanks (PB) are evaluated for each matrix, with every SDG, or with each batch of samples digested, whichever is more frequent. The analyte concentration in the PB should be below the contract required detection limit (CRDL). If any analyte concentration in the PB is above the CRDL, the lowest concentration of that analyte in the associated samples must be ten times (10X) the PB concentration. Otherwise, all samples associated with the PB with the analyte's concentration less than 10X the PB concentration, and above the CRDL, should be redigested and reanalyzed. If the concentration of the PB is less than or equal to the CRDL, no corrective action to the associated sample is required.

Surrogate spikes, or system monitoring compounds, are added to the environmental samples analyzed by chromatographic techniques for VOCs, SVOCs, pesticides, and TPH diesel and gasoline for the Area 22 Sewage Lagoons. Surrogate compounds are analytes that are not expected to be present in associated environmental samples, but behave the same as similar target compounds chromatographically. Known amounts of each surrogate are added prior to sample preparation and are carried throughout the preparation/analysis procedure. The percent recoveries of these surrogate compounds give some measure of the anticipated recoveries of the target compounds whose chromatographic behavior they mimic.

If any surrogate percent recoveries are out of the acceptable range (which differs for each surrogate in each method), laboratory protocol calls for the sample to be reprepared and/or reanalyzed. When the surrogate recoveries are acceptable on the second run, only the second analysis results are reported. When both analyses yield the same unacceptable range, the results of both analyses are reported.

The evaluation of surrogate spike percent recovery results is not straightforward. The functional guidelines suggest several optional approaches, but require the data reviewer to exercise professional judgement in reviewing surrogate data and qualifying associated data as estimated ( $\mathrm{J}$ or $\mathrm{UJ}$, for detections or nondetections, respectively) or unusable (R). 
One laboratory duplicate was prepared and analyzed for each group of samples with similar matrix or for each SDG for total RCRA metals and TCLP RCRA metals analyses. The laboratory duplicate results were compared to the results of the original sample to give a measure of analytical laboratory precision. If the results from a duplicate analysis for a particular analyte fall outside the RPD control limits, the EPA Functional Guidelines for Inorganic Data Review (EPA, 1994a) call for all results for that analyte in all associated samples of the same matrix to be qualified as estimated $(\mathrm{J})$.

Laboratory control samples, also known as blank spikes, consist of known concentrations of target compounds added to purified sand or deionized, distilled water prepared and analyzed along with the environmental samples in the sample delivery group. The percent recoveries of the compounds in the LCS give a measure of laboratory accuracy. The functional guidelines call for the data reviewer to use professional judgement to qualify associated data according to established criteria.

Documentation of data qualifications resulting from the application of these guidelines is retained in project files as both hard copy and electronic media.

\section{A.4.8 Field Nonconformances}

During the corrective action investigation, a QA surveillance was conducted by IT Corporation to verify that sampling activities were performed in accordance with applicable requirements. The results of the QA surveillance indicated no findings, deficiencies, or nonconformances with sampling activities. Sampling activities met the requirements of the plans and procedures governing the activities at the site.

\section{A.4.9 Laboratory Nonconformances}

Laboratory nonconformances are generally due to inconsistencies in analytical instrumentation operation, sample preparations/extractions, analysis and fluctuations in internal standard and calibration results. The laboratory is not required to generate nonconformance for this type of deficiency as long as the laboratory met all the required QC criteria for the initial calibration analysis. However, the laboratory is required to generate nonconformance for holding time deficiency. A nonconformance was documented for the SVOC reextraction outside the holding time for sample 22SL017A. The reextracted sample results were qualified as estimated due to the holding time nonconformance. Documentation of these results is retained in project files. 


\section{A.5.0 Summary}

Analysis of the data generated from corrective action investigation activities conducted at the CAU 230/320, Area 22 Sewage Lagoons indicates the following:

- All total VOC, SVOC, and TPH as gasoline-range organics results were below the PALs stated in the CAIP (DOE/NV, 1999).

- Three samples from the sludge bed area have TPH as diesel-range organics concentrations ranging from $150 \mathrm{mg} / \mathrm{kg}$ to $580 \mathrm{mg} / \mathrm{kg}$ and are above the NDEP action level of $100 \mathrm{mg} / \mathrm{kg}$.

- The minimum reporting limits were not exceeded for TCLP VOC, TCLP SVOC, TCLP RCRA metals, or TCLP pesticides (DOE/NV, 1999)

- Results for gamma-emitting radionuclides were below the PALs stated in the CAIP (DOE/NV, 1999)

- Excavation of the sludge bed area uncovered asphalt debris and soil with four yellow and black-stripped safety poles and strands of barbed wire. The debris did not extend beyond approximately $9 \mathrm{ft}$ bgs. The results of the magnetic survey indicate the area of the debris is approximately $50 \mathrm{ft}$ X $50 \mathrm{ft}$. 


\section{A.6.0 References Cited}

BN, see Bechtel Nevada.

Bechtel Nevada. 1999. Results of the land survey for the CAU 230/320 sample locations conducted by Bechtel Nevada, 30 September. Las Vegas, NV.

DOE, see U.S. Department of Energy.

DOE/NV, see U.S. Department of Energy, Nevada Operations Office.

EPA, see U.S. Environmental Protection Agency.

FFACO, see Federal Facility Agreement and Consent Order.

Federal Facility Agreement and Consent Order. 1996 (as amended). Agreed to by the State of Nevada, the U.S. Department of Energy, and the U.S. Department of Defense.

IT, see IT Corporation, Las Vegas Office.

IT Corporation, Las Vegas Office. 1999. Site-Specific Health and Safety Plan for the Corrective Action Investigation for the CAU 230/320 Area 22 Sewage Lagoons, Nevada Test Site. Las Vegas, NV.

McArthur, R.D., and F.L. Miller, Jr. 1989. Off-Site Radiation Exposure Review Project Phase II Soil Program, DOE/NV/10384--23. Las Vegas, NV: Desert Research Institute.

NAC, see Nevada Administrative Code.

NDEP, see Nevada Division of Environmental Protection.

Nevada Administrative Code. 1999. NAC 445A.2272, "Contamination of soil: Order by director of corrective action; factors to be considered in determining whether corrective action is required." Carson City, NV.

Nevada Division of Environmental Protection. 1994. Water Pollution Control General Permit, GNEV93001. Carson City, NV: Bureau of Federal Facilities.

Nevada Division of Environmental Protection. 1997. Letter from Verae Rosse to Kenneth A. Hoar (DOE/NV) regarding "Revision of General Water Pollution Control Permit," 30 April. Las Vegas, NV. 
Nevada Division of Environmental Protection. 1999. Letter from Paul Liebendorfer to Kenneth A. Hoar (DOE/NV) regarding "Reissuance of Water Pollution Control Permit GNEV93001,” 29 October. Carson City, NV: Bureau of Federal Facilities.

RSL, see Remote Sensing Laboratory.

Remote Sensing Laboratory. 1990. Aerial photograph \#6794-08 taken at 11,000 feet above the Camp Desert Rock Facility. Nellis Air Force Base, NV: Photo Archive Library.

Robie, L., S. Reiner, and G. Locke. 1995. Ground-Water Data for the Nevada Test Site, 1992, and for Selected Other Areas in South-Central Nevada, 1952-92, USGS-OFR-284. Denver, CO: U.S. Geological Survey.

USACE, see U.S. Army Corps of Engineers.

U.S. Army Corps of Engineers. 1958. "Basic Information Maps for Camp Desert Rock." Barstow, CA.

U.S. Department of Energy. 1997. Environmental Measurements Laboratory Procedures Manual, HASL-300, 28th Edition, Vol. 1. New York, NY.

U.S. Department of Energy, Nevada Operations Office. 1996. Industrial Sites Quality Assurance Project Plan, Nevada Test Site, Nevada, Rev. 1, DOE/NV--372. Las Vegas, NV.

U.S. Department of Energy, Nevada Operations Office. 1999. Corrective Action Investigation Plan for Corrective Action Unit 230, Area 22 Sewage Lagoons and Corrective Action Unit 320, Area 22 Desert Rock Airport Strainer Box, Nevada Test Site, Nevada, Rev. 0, DOE/NV--552. Las Vegas, NV.

U.S. Ecology and Atlan-Tech. 1992. Environmental Monitoring Report for the Proposed Ward Valley California Low Level Radioactive Waste (LLRW) Facility. Roswell, GA: Atlan-Tech, Inc.

U.S. Environmental Protection Agency. 1980. Prescribed Procedures for Measurements of Radioactivity in Drinking Water, EPA-600/4-80-032. Washington, DC.

U.S. Environmental Protection Agency. 1987. Data Quality Objectives for Remedial Response Activities, EPA/540/G-87-003. Washington, DC.

U.S. Environmental Protection Agency. 1994a. Contract Laboratory Program National Functional Guidelines for Inorganic Data Review, EPA 540/R-94/013. Washington, DC.

U.S. Environmental Protection Agency. 1994b. Contract Laboratory Program National Functional Guidelines for Organic Data Review, EPA 540/R-94/012. Washington, DC. 
U.S. Environmental Protection Agency. 1994c. Guidance for the Data Quality Objectives Process, EPA QA/G-4. Washington, DC.

U.S. Environmental Protection Agency. 1996. Test Methods for Evaluating Solid Waste, Physical/Chemical Methods, SW-846, CD ROM PB97-501928GEI which contains updates for 1986, 1992, 1994 and 1996. Washington, DC.

U.S. Environmental Protection Agency. 1998. Memo from S.J. Smucker, to PRG Table Mailing List regarding update of the Region 9 Preliminary Remediation Goals (PRGs), 1 August.

San Francisco, CA.

Winograd, I.J., and W. Thordarson. 1975. Hydrologic and Hydrochemical Framework, South-Central Great Basin, Nevada-California, with Special Reference to the Nevada Test Site, U.S. Geological Survey Professional Paper 712C. Washington, DC: U.S. Government Printing Office. 
Appendix B

Cost Estimates 


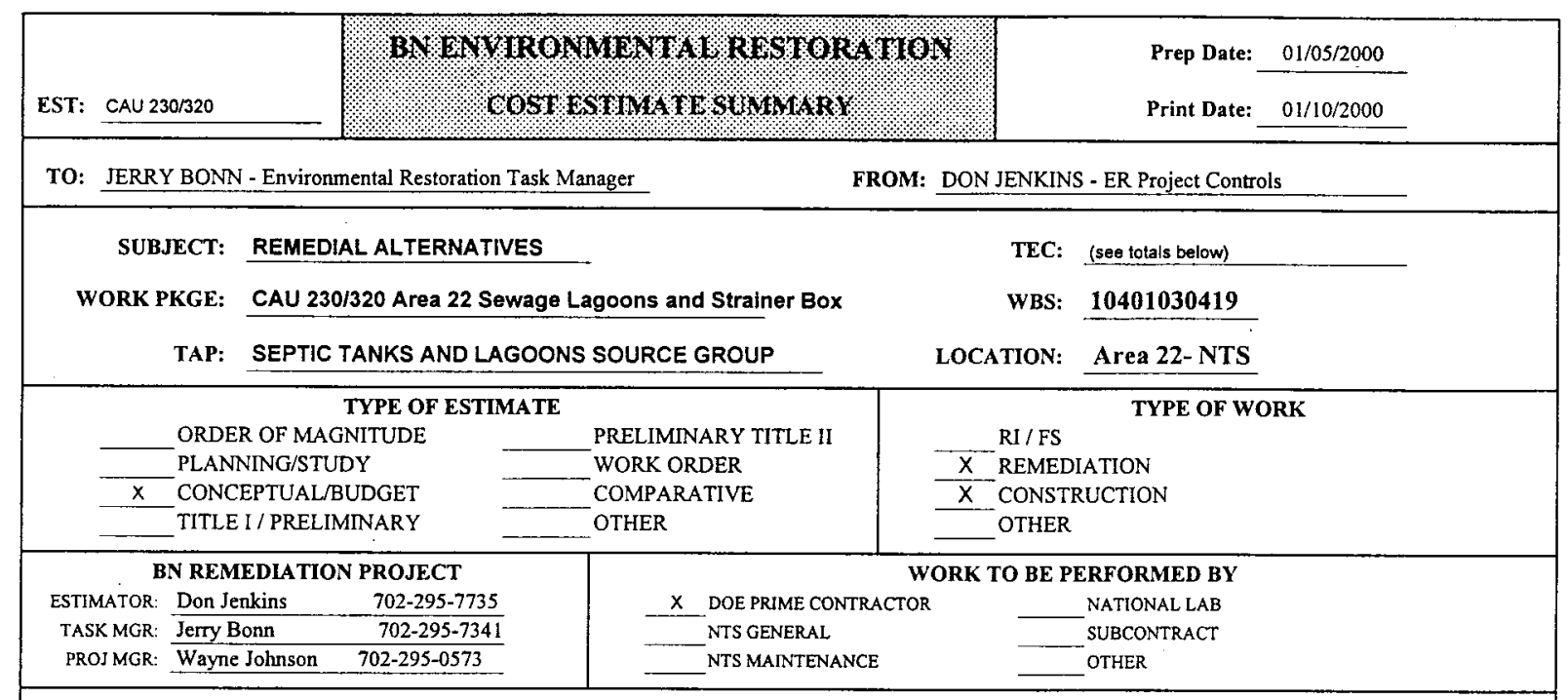

STATEMENT OF WORK:

This estimate has been prepared to provide remedial alternative costs for the closure of Corrective Action Unit (CAU) 230/320, an environmental restoration site listed in the Federal Facility Agreement and Consent Order. CAU 230/320 is specifically described as Area 22 Sewage Lagoons and Strainer Box. Three alternatives will be evaluated for closure of the site: I) No Further Action, No associated Costs, or Administrative Controls, II) Closure in Place with Administrative Controls, and III) Excavation and removal No administrative controls implied. This estimate will be used to identify the most cost effective alternative for closure of the site while being protective of human health and the environment. Total estimated costs are intended for comparative analysis of remedial field work and field management only. Cost for project management, plan preparation, project support, or other overhead functions are not included.

SCOPE

Provide site closure using one of the following alternatives:

I) NO FURTHER ACTION -NO ASSOCIATED COSTS OR ADMINISTRATIVE CONTROLS

II) CLOSURE IN PLACE WITH ADMINISTRATIVE CONTROLS

III) EXCAVATION AND REMOVAL-NO ADMINISTRATIVE CONTROLS IMPLIED

\section{ALTERNATIVE SPECIEIC BASIS OF ESTIMATELASSUMPTIONS}

Alternative II: Closure In Place with Administrative Controls

- Sludge bed surface area $50 \mathrm{ft}$ X $50 \mathrm{ft}$.

- Conduct geotechnical sampling (minimum of two samples)

- A Geosynthetic Clay Liner (GCL) in conjunction with $2 \mathrm{ft}$ of processed bedding material will be required to achieve a permeability less than the surrounding soil.

- Grade surrounding area to assure no run on.

- Grout Strainer Box ( $3 \mathrm{ft} \times 3 \mathrm{ft} \times 3 \mathrm{ft})$

- Grout approximately six to eight manholes (and/or open and exposed piping)

- Stabilize soil over Imhoff Tank to prevent the potential for subsidence or erosion (backfill depression area and compact)

- T-Post strand wire fence and signage around the sludge bed site

- Assume inspections and maintenance of the cover will be conducted for a period of 20 years. Cost associated with annual report is not a part of this estimate.

- Cost associated with any repair required for the cover is not a part of this estimate

\section{Alternative III: Excavation and Removal-NoAdministrative Controls Implied (Clean Closure)}

- Sludge bed surface area $50 \mathrm{ft} X 50 \mathrm{ft}$

- Remove and dispose of $(670 \mathrm{CY})$ hydrocarbon impacted soils, asphalt, and construction debris. This volume includes a $20 \%$ expansion factor.

- Collect 5 verification samples for TPH analysis

- Backfill with borrow pit clean soil and wheel roll surface for compaction using heavy equipment. Assume no processing required.

- Grade to surrounding topography.

- Grout Strainer Box ( $3 \mathrm{ft} X 3 \mathrm{ft} \mathrm{X} 3 \mathrm{ft})$

- Grout approximately six to eight manholes (and/or open and exposed piping)

- Stabilize soil over Imhoff Tank to prevent the potential for subsidence or erosion (backfill depression area and compact) 


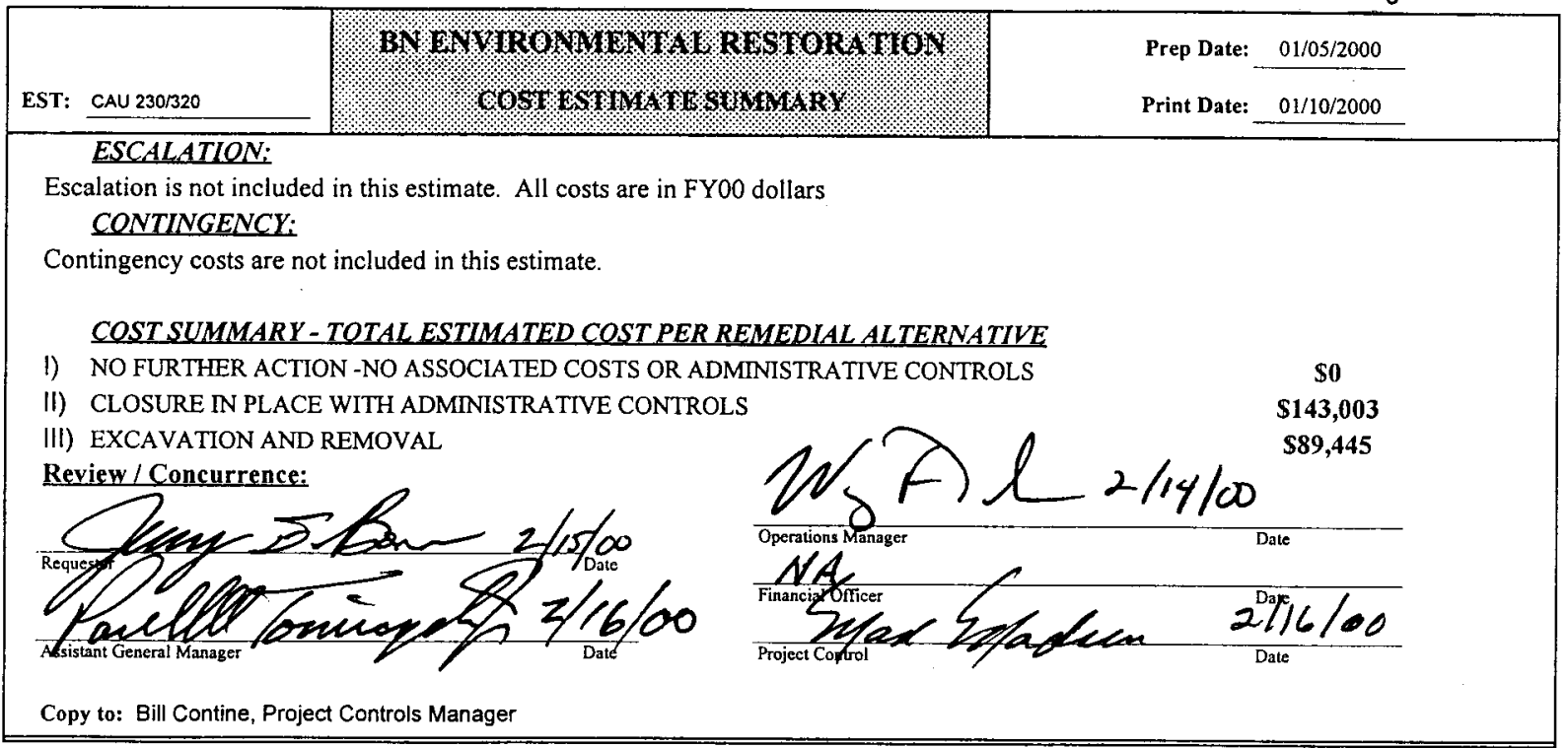




\section{Appendix C}

Evaluation of Risk 


\section{C.1.0 Evaluation of Risk}

A detailed assessment of risk for no action and evaluated alternatives was not performed for CAU 230/320 because the COC exceeding the PAL will not be left in place without appropriate controls. 
Appendix D

Manhole Investigation/CADD Photos 
On March 14 and 15, 2000, at the request of NDEP, each of the manholes associated with the septic system leading to the Imhoff Tank was inspected to determine the presence of any residual solids/sludges. The manholes are numbered on Figure D-1 and described in Table D-1. Photographs of selected manholes are also included in this appendix.

Sludge was not found in any of the manholes. Manholes 3, 6, 13, 18, and 22 contained only trace amounts of soil particles, rodent excreta, and debris. Since the system was abandoned 35 to 40 years ago, many of the concrete manhole covers have crumbled into the manholes below or were not in place. This has allowed surface debris and soil to enter the septic system piping. Solids in the manholes strongly resemble the soil and gravel at the surface which supports that the soil has fallen in over the years. Solids in the manholes are too large to have entered the system through designed entry points other than the manholes. Soil media found in Manhole 13 could have been sampled for verification; however, significant amounts of rodent excreta were present with the soil media.

In this region, the presence of rodent excreta heightens the probability for the hantavirus. The solids were not sampled because an analytical laboratory could not be identified to process samples potentially containing the hantavirus. Solids found in the manholes appear to be incidental to post operations system decay and passive influent, and therefore, not contaminated by operational discharges to the system. 


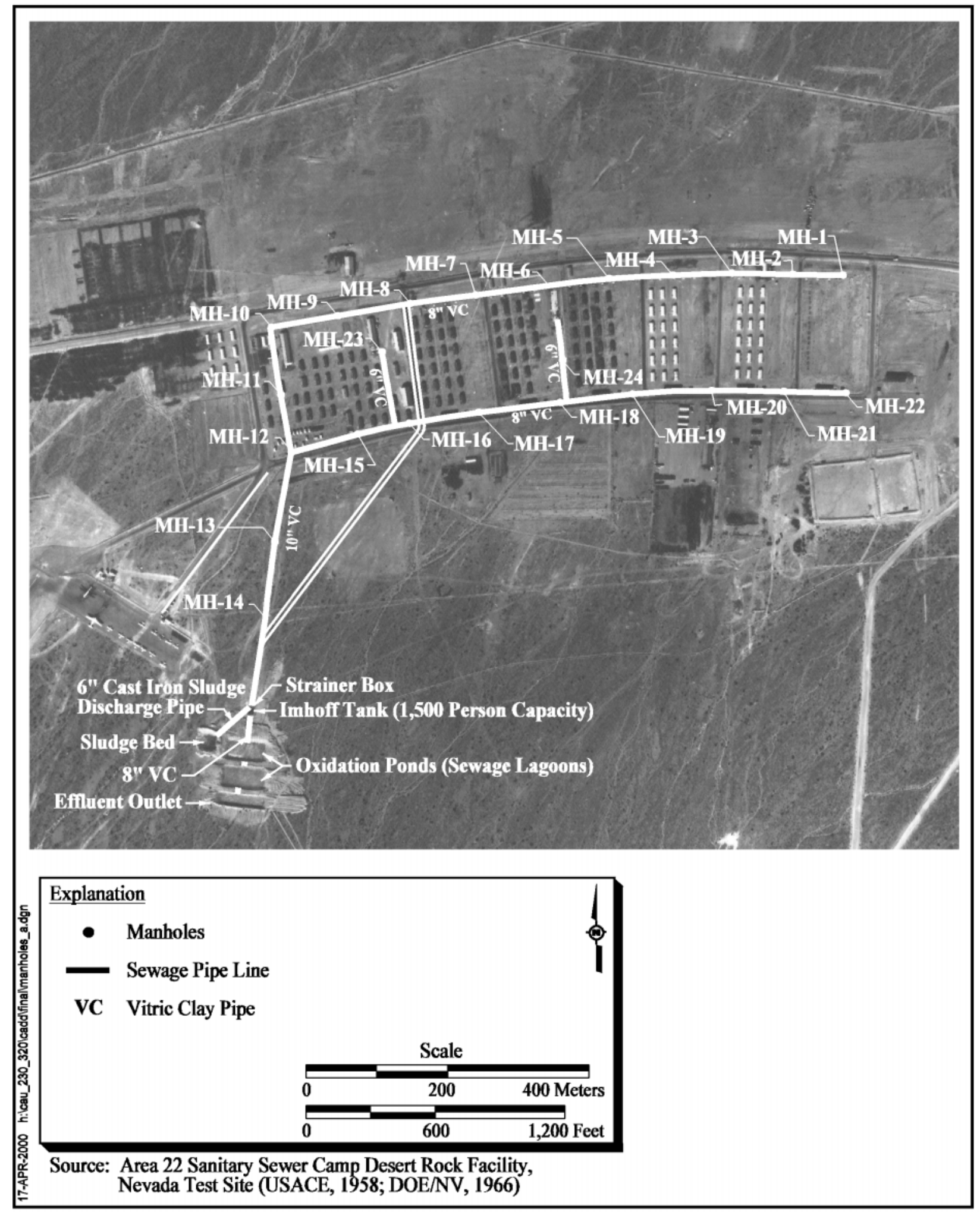

Figure D-1

CAU 230/320 Manhole Locations

Area 22, Nevada Test Site 


\section{Table D-1 \\ Manhole Investigation Descriptions}

\begin{tabular}{|c|c|}
\hline Manhole & Manhole Condition \\
\hline 1 & Insufficient sediment volume, dry \\
\hline 2 & Unable to estimate sediment volume due to plant brush in manhole, lid previously removed \\
\hline 3 & $\begin{array}{l}\text { Insufficient sediment volume, organic (rodent excreta present) material, dry, large chunks of } \\
\text { concrete from broken manhole cover }\end{array}$ \\
\hline 4 & $\begin{array}{l}\text { Insufficient sediment volume, organic (rodent excreta present) material, dry, large chunks of } \\
\text { concrete from broken manhole cover }\end{array}$ \\
\hline 5 & Insufficient sediment volume, dry \\
\hline 6 & Unable to estimate sediment volume, manhole lid removed, contained sheet metal and misc. debris \\
\hline 7 & $\begin{array}{l}\text { Sediment (gravels and soil) volume questionable, dry, organic (rodent excreta present) material, dry, } \\
\text { pad labeled "F-29-52," interpretation--built on } 2 / 29 / 1952\end{array}$ \\
\hline 8 & Insufficient sediment volume, dry, rodent excreta present \\
\hline 9 & Unable to remove lid, lid was crumbling \\
\hline 10 & Insufficient sediment volume, dry, concrete lid crumbled and fell into manhole \\
\hline 11 & Insufficient sediment volume, moist, rodent excreta present \\
\hline 12 & Manhole cover replaced with metal lid, no description, see photos \\
\hline 13 & $\begin{array}{l}\text { Sufficient sediment volume, manhole lid had been removed (check photo to confirm), contains } \\
\text { mostly organic debris }\end{array}$ \\
\hline 14 & Unable to remove lid, covered with gravel, located next to new airport road \\
\hline 15 & Dry insufficient sediment volume, organic (rodent excreta present) material \\
\hline 16 & $\begin{array}{l}\text { No photo available. Insufficient sediment volume, moist contents, ponding water, appears that } \\
\text { concrete lid was replaced with metal (e.g., iron) lid, appears that material unrelated to the manhole } \\
\text { was dumped in, concrete pad labeled "F-28-52" (interpreted as built on 2/28/1952) }\end{array}$ \\
\hline 17 & Insufficient sediment volume, dry \\
\hline 18 & $\begin{array}{l}\text { Sufficient sediment (gravels and soil) volume, dry, abundant organic (rodent excreta present) } \\
\text { material }\end{array}$ \\
\hline 19 & More than enough sediment volume, dry, organic (rodent excreta present) material \\
\hline 20 & Insufficient sediment volume, dry, manhole lid had been previously removed \\
\hline 21 & Insufficient sediment volume, dry \\
\hline 22 & More than enough sediment volume, dry \\
\hline 23 & $\begin{array}{l}\text { Sufficient sediment volume, dry, staining from organic decay (?), rodent excreta present, mostly } \\
\text { organic plan debris (e.g., animal nests) }\end{array}$ \\
\hline 24 & Sufficient sediment volume in open pipe, moist \\
\hline
\end{tabular}




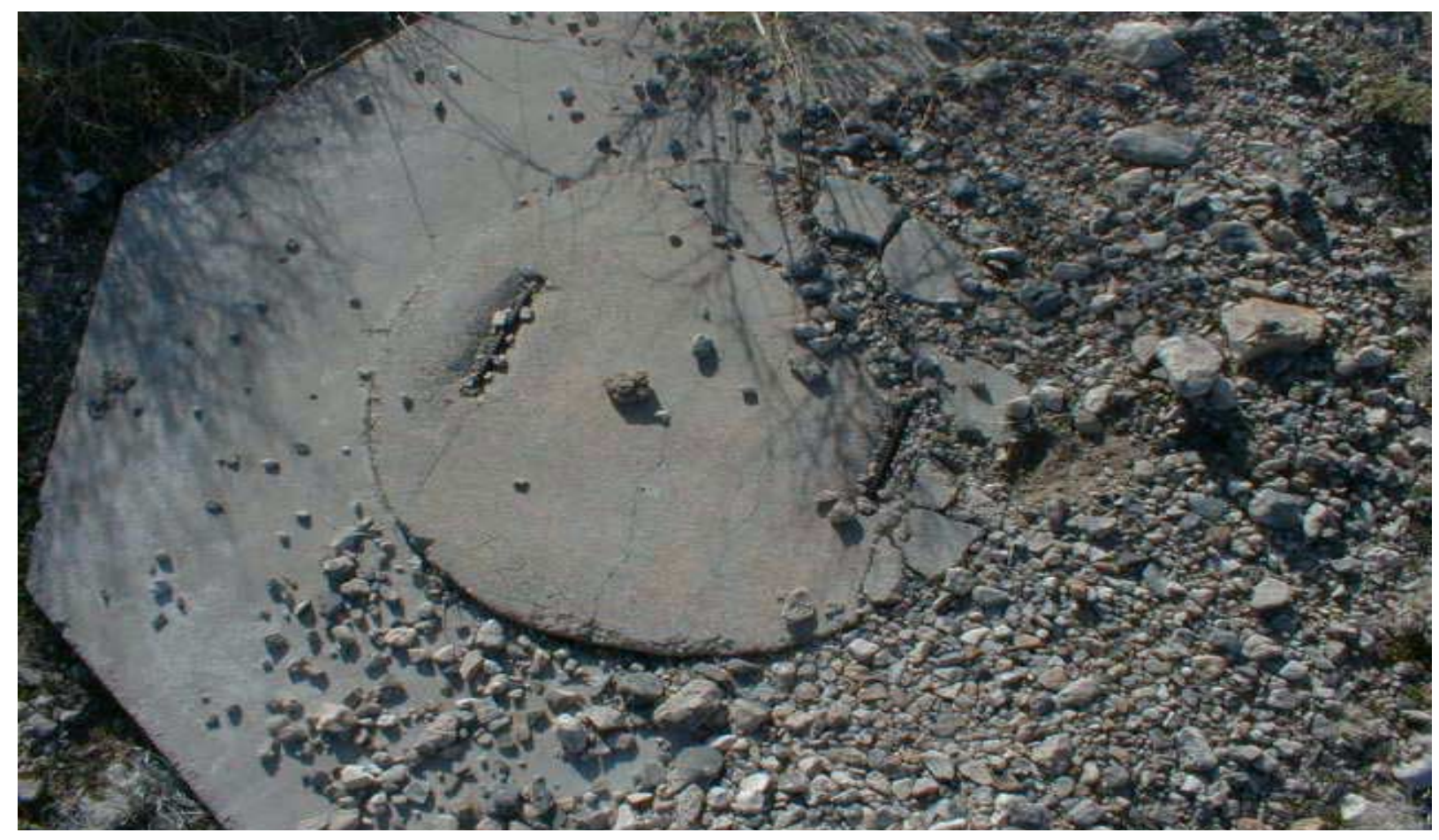

\section{Manhole 3 Surface}

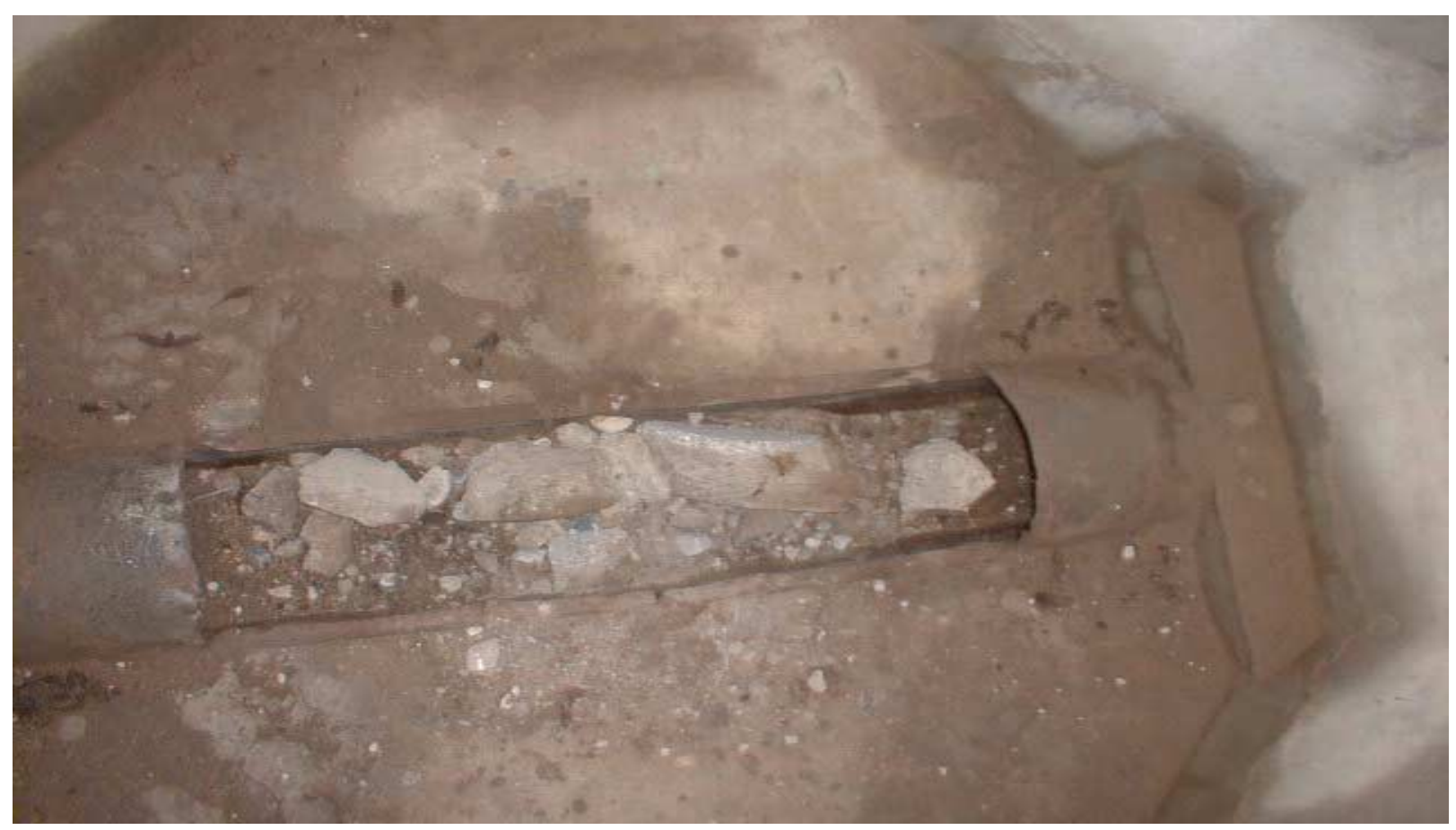




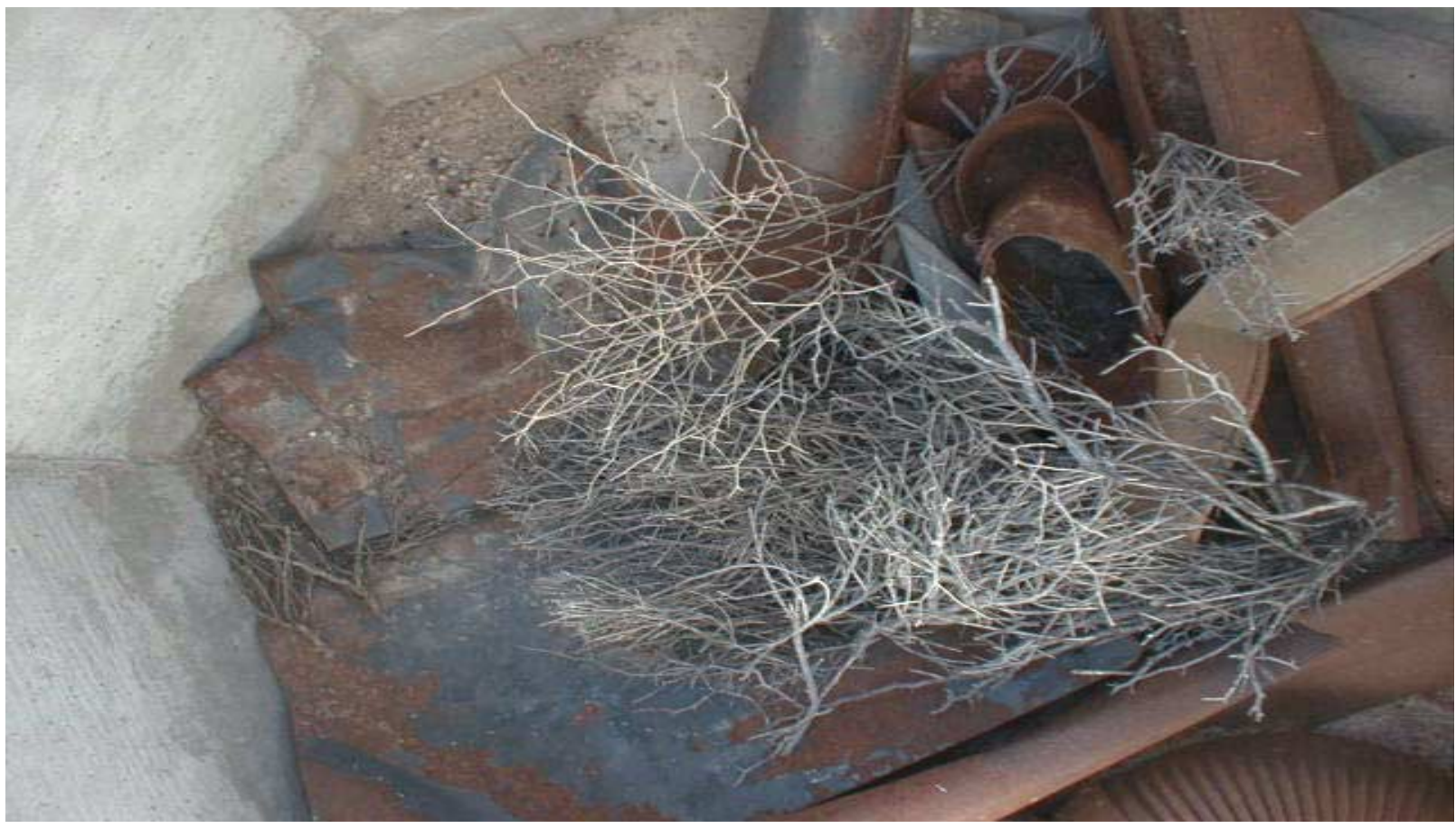

\section{Manhole 6 Interior}

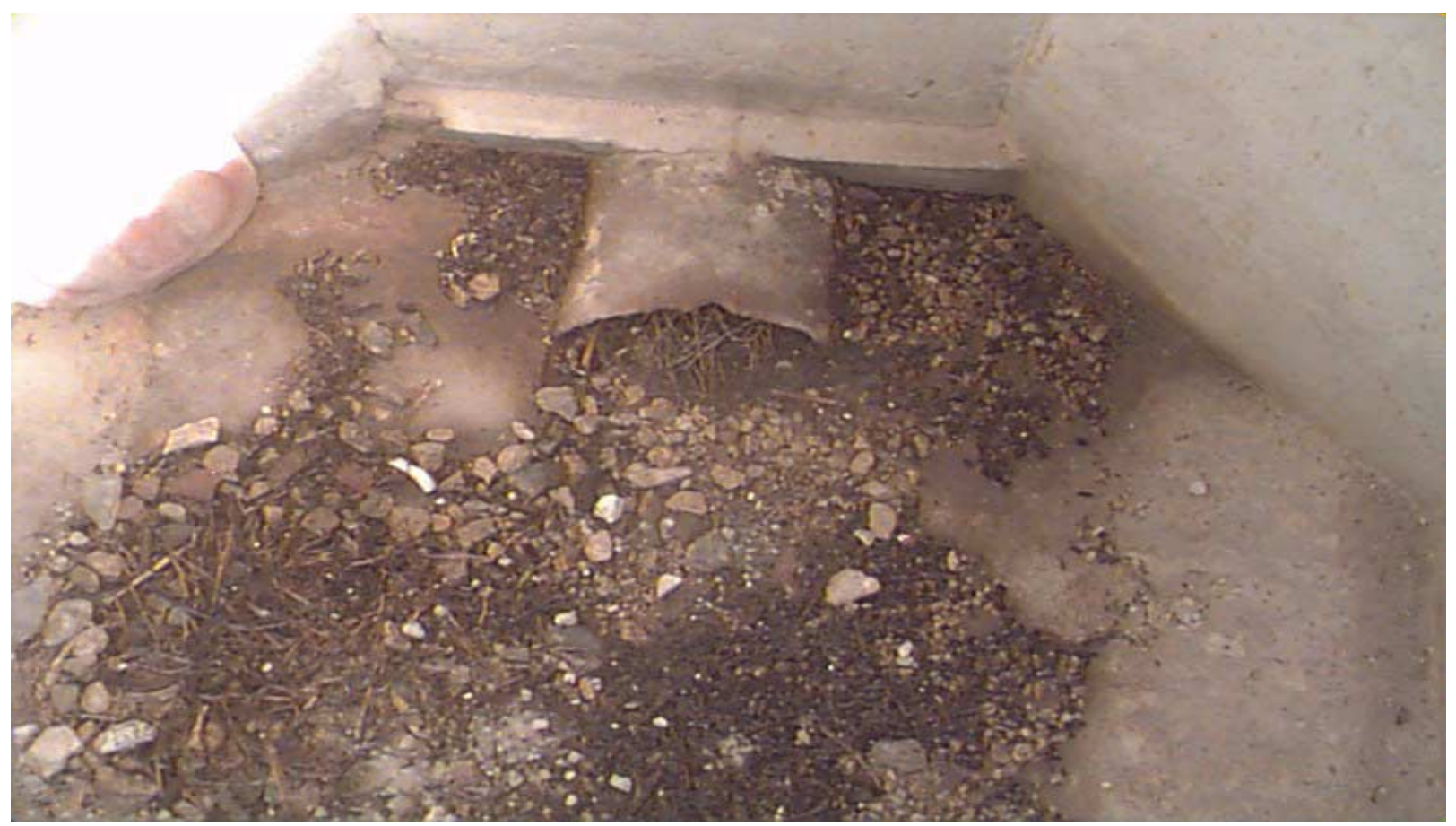

\section{Manhole 18 Interior}




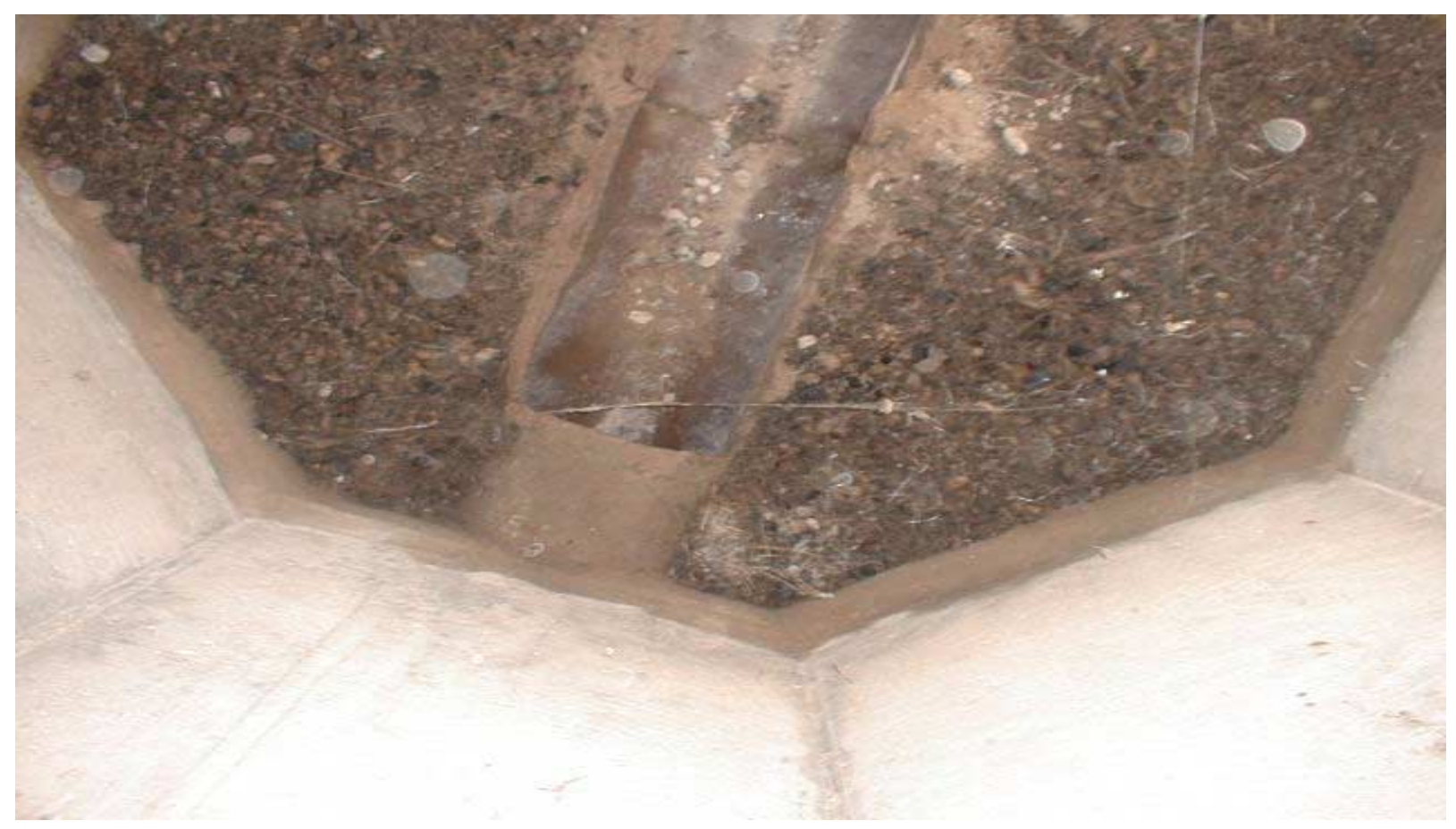

\section{Manhole 13 Interior}

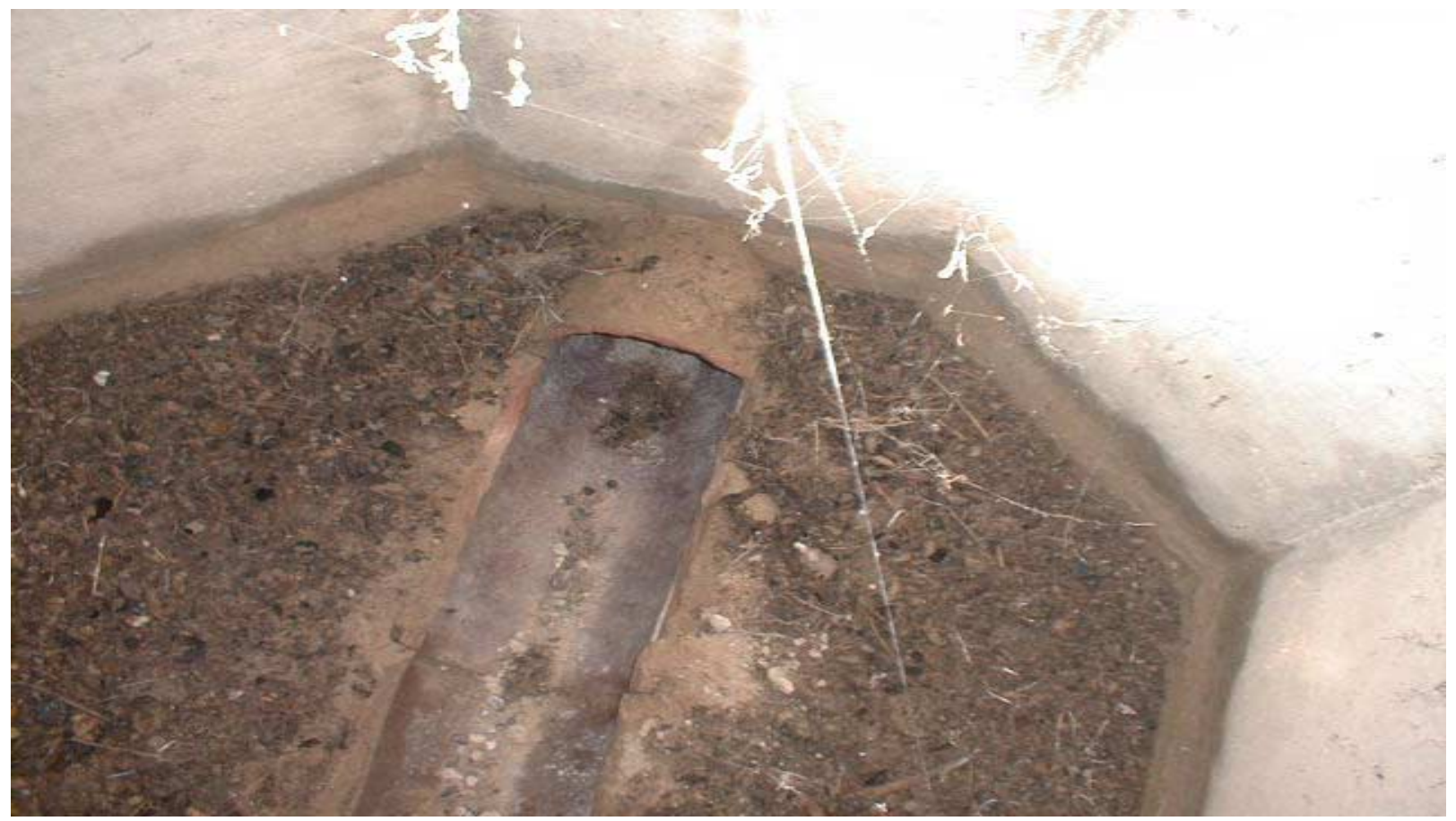

Manhole 13 Interior 


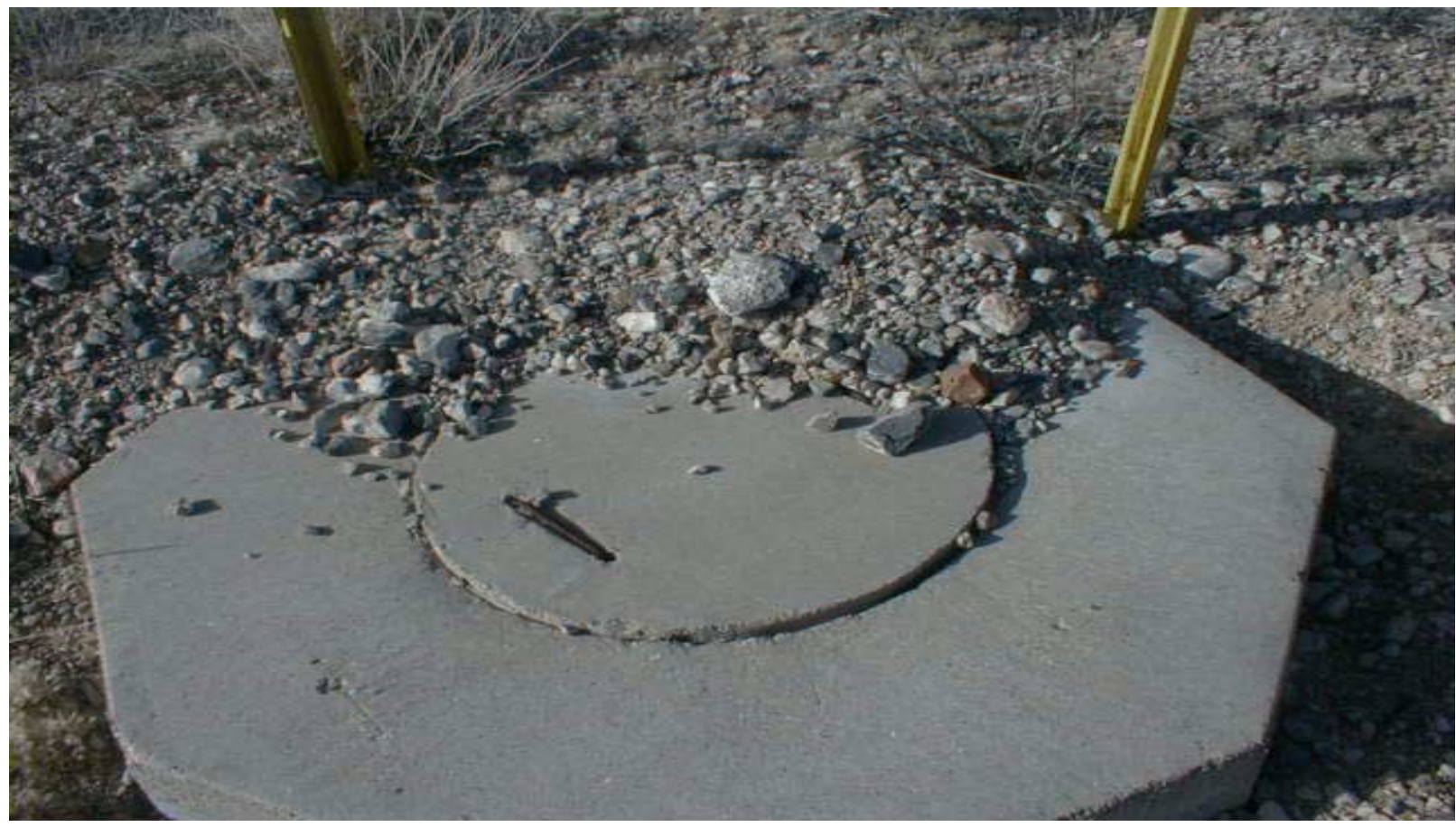

\section{Manhole 22 Surface}

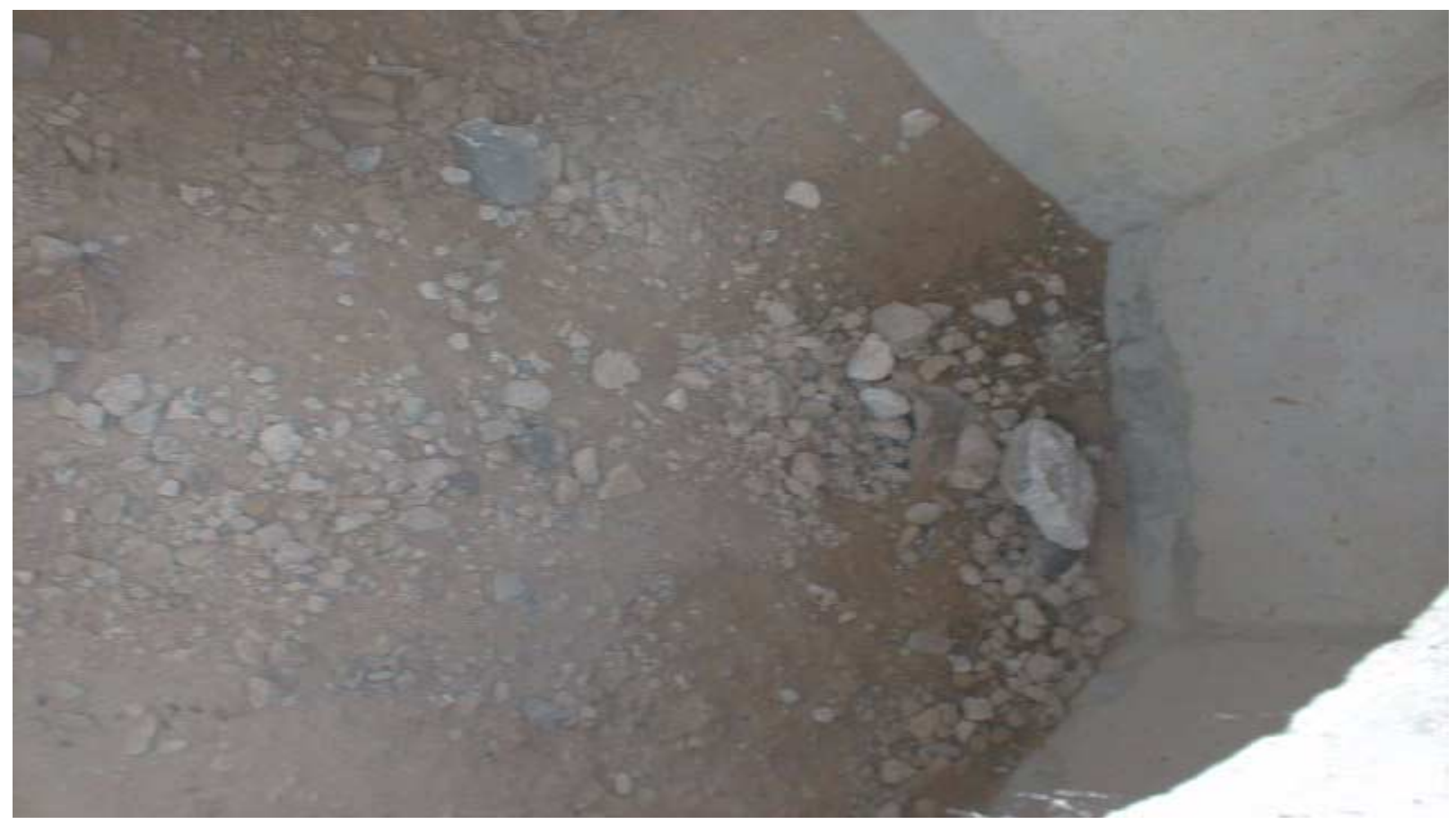

Manhole 22 Interior 


\section{D.1.0 References}

DOE/NV, see U.S. Department of Energy, Nevada Operations Office.

USACE, see U.S. Army Corp of Engineers.

U.S. Army Corp of Engineers. 1958. "Basic Information Maps for Camp Desert Rock." Barstow, CA.

U.S. Department of Energy, Nevada Operations Office. 1966. Aerial Photograph of the Camp Desert Rock Facility taken on January 18. Las Vegas, NV: ITLV Technical Information Center Photographs. 


\section{Appendix E}

\section{Response to NDEP Comments}


NEVADA ENVIRONMENTAL RESTORATION PROJECT

DOCUMENT REVIEW SHEET

\begin{tabular}{|c|c|c|c|c|c|}
\hline \multicolumn{4}{|c|}{$\begin{array}{l}\text { 1. Document Title/Number: } \\
\qquad \begin{array}{l}\text { Draft Corrective Action Decision Document for CAU 230: Area } 22 \text { Sewage } \\
\text { Lagoons and CAU 320: Area } 22 \text { Desert Rock Airport Strainer Box, Nevada Test } \\
\text { Site, Nevada }\end{array}\end{array}$} & \multicolumn{2}{|l|}{ 2. Document Date: February 2000} \\
\hline \multicolumn{4}{|c|}{ 3. Revision Number: 0} & \multicolumn{2}{|l|}{ 4. Originator/Organization: IT Corporation } \\
\hline \multicolumn{4}{|c|}{ 5. Responsible DOE/NV ERD Project Mgr.: Janet Appenzeller-Wing } & \multicolumn{2}{|l|}{ 6. Date Comments Due: March 9, 2000} \\
\hline \multicolumn{6}{|c|}{ 7. Review Criteria: Full } \\
\hline \multicolumn{4}{|c|}{ 8. Reviewer/Organization/Phone No.: Gregory A. Raab - NDEP } & \multicolumn{2}{|l|}{ 9. Reviewer's Signature: } \\
\hline $\begin{array}{l}\text { 10. Comment } \\
\text { Number/ } \\
\text { Location }\end{array}$ & 11. Type* & 12. Comment & & 13. Comment Response & $\begin{array}{c}14 . \\
\text { Accept }\end{array}$ \\
\hline $\begin{array}{l}\text { 1. Page 13, Part e, } \\
\text { 3rd Sentence and } \\
\text { Subsequent Bullets }\end{array}$ & & $\begin{array}{l}\text { "...Any downward migration of the COC...' This sentence and its } \\
\text { related bullets should be moved to part } \mathrm{h} \text { below which addresses } \\
\text { routes of migration and limitations. }\end{array}$ & $\begin{array}{l}\text { The text has } \\
\text { comment. }\end{array}$ & en moved and/or modified to address this & Yes \\
\hline 2. Page 13, Part $h$ & & $\begin{array}{l}\text { There is nothing here to indicate what the routes of migration are, } \\
\text { only limitations to migration. Please describe the routes of migration } \\
\text { before discussing the limitations impeding them. }\end{array}$ & $\begin{array}{l}\text { The routes } 0 \\
\text { sentence. }\end{array}$ & igration have been added to the introductory & Yes \\
\hline $\begin{array}{l}\text { 3. Page A-6, } \\
\text { Fig. A.2-1 }\end{array}$ & & $\begin{array}{l}\text { The list of Location Numbers have a different designation than the } \\
\text { sample numbers in the text and subsequent tables. Please describe } \\
\text { in text or in a table the data from GP\#17 is listed in Table A.2-1 as } \\
\text { 22SLO17A or B. }\end{array}$ & $\begin{array}{l}\text { Text in Secti } \\
\text { A.3-3, and A }\end{array}$ & $\begin{array}{l}\text { A.2.1.1, Figure A.2-1, and Table A.2-1, A.3-2, } \\
4 \text { were modified to address this comment. }\end{array}$ & Yes \\
\hline $\begin{array}{l}\text { 4. Page A-6, } \\
\text { Fig. A.2-1 }\end{array}$ & & $\begin{array}{l}\text { This figure indicates there is a 10" vitrified clay (VC) line discharging } \\
\text { into the Imhoff Tank. The text does not indicate that the piping was } \\
\text { sampled. As this sewer line is included as part of this CAU, it must } \\
\text { be evaluated. The character of any residual solids/sludges } \\
\text { remaining in the system is the principle concern. If the intent is to } \\
\text { leave this piping in place, DOE must provide documentation the } \\
\text { piping is not contaminated. }\end{array}$ & $\begin{array}{l}\text { The piping } n \\
\text { element of th } \\
\text { the manhole } \\
\text { Imhoff Tank } \\
\text { manholes ap } \\
\text { decay and p } \\
\text { by operation } \\
\text { sampled bec } \\
\text { process sam } \\
\text { Appendix D }\end{array}$ & $\begin{array}{l}\text { not sampled because this activity was not an } \\
\text { original scope approved in the CAIP. Each of } \\
\text { ssociated with the septic system leading to the } \\
\text { e been inspected. Solids found in the } \\
\text { ar to be incidental to post operations system } \\
\text { ive influent, and therefore, not contaminated } \\
\text { lischarges to the system. The solids were not } \\
\text { se a laboratory could not be identified to } \\
\text { potentially containing the hantavirus. } \\
\text { tains supporting information. }\end{array}$ & Yes \\
\hline
\end{tabular}

${ }^{a}$ Comment Types: $\mathrm{M}$ = Mandatory, $\mathrm{S}=$ Suggested.

Return Document Review Sheets to DOE/NV Environmental Restoration Division, Attn: QAC, M/S 505. 


\section{Distribution}

*Provide copy in distribution of Rev. 0 and subsequent revisions if applicable. Copies of only the NDEP-approved document will be distributed to others.

$\underline{\text { Copies }}$

Paul J. Liebendorfer

State of Nevada

Bureau of Federal Facilities

Division of Environmental Protection

333 W. Nye Lane, Room 138

Carson City, NV 89706-0851

Michael McKinnon

State of Nevada

Bureau of Federal Facilities

Division of Environmental Protection

555 E. Washington, Suite 4300

Las Vegas, NV 89101

Sabrina Lawrence

Environmental Restoration Division

DOE/Nevada Operations Office

P.O. Box 98518, M/S 505

Las Vegas, NV 89193-8518

Janet Appenzeller-Wing

Environmental Restoration Division

DOE/Nevada Operations Office

P.O. Box 98518, M/S 505

Las Vegas, NV 89193-8518

Sabine Curtis

Environmental Restoration Division

DOE/Nevada Operations Office

P.O. Box 98518, M/S 505

Las Vegas, NV 89193-8518

Wayne Johnson

Bechtel Nevada

P.O. Box 98521, M/S NTS306

Las Vegas, NV 89193-8521
2 (Controlled)*

1 (Controlled)*

1 (Controlled)*

1 (Uncontrolled)*

1 (Uncontrolled)*

1 (Uncontrolled)* 
Dennis Gustafson

Bechtel Nevada

P.O. Box 98521, M/S NTS306

Las Vegas, NV 89193-8521

IT Corporation Central Files

IT Corporation

P.O. Box 93838

Las Vegas, NV 89193

Dustin Wilson

SAIC

P.O. Box 93838

Las Vegas, NV 89193

Technical Information Resource Center

DOE/Nevada Operations Office

P.O. Box 98518, M/S 505

Las Vegas, NV 89193-8518

U.S. Department of Energy

Office of Scientific and Technical Information

P.O. Box 62

Oak Ridge, TN 37831

Manager Southern Nevada FFACO

Public Reading Room

P.O. Box 98521, M/S NLV040

Las Vegas, NV 89193-8521

Northern Nevada FFACO PRR

Nevada State Library and Archives

Federal Publications

100 North Stewart Street

Carson City, NV 89701-4285

FFACO Public Reading Room Coordinator

FFACO Support Office

IT Corporation

P.O. Box 93838

Las Vegas, NV 89193
1 (Uncontrolled)*

1 (Uncontrolled)*

1 (Uncontrolled)*

1 (Uncontrolled)

1 (Uncontrolled, electronic copy)

1 (Controlled)

1 (Uncontrolled)

1 (Uncontrolled)

1 (Controlled) 